\title{
New genera and species of subterranean Anilline Bembidiini from the Pilbara, north- western Australia (Insecta: Coleoptera: Carabidae: Bembidiini: Anillina)
}

\author{
Martin Baehr ${ }^{1}$ and Dean Main² \\ 1 Zoologische Staatssammlung, Münchhausenstr. 21, D-81247 München, Germany. \\ ${ }^{2}$ Bennelongia Environmental Consultants, 5 Bishop Street, Joilimont, Western Australia 6014, Australia. \\ *Corresponding author: martin.baehr@zsm.mwn.de
}

\begin{abstract}
Six new genera and 17 new species of the carabid tribe Bembidiini, subtribe Anillina, are described from the Pilbara in north-western Australia and from inland southern Western Australia: Macranillus gen. nov.: M. bennetti sp. nov., M. magnus sp. nov., M. maini sp. nov., M. pearsoni sp. nov., M. quartermainei sp. nov.; Pilbaranillus gen. nov.: P. latibasis sp. nov.; Gracilanillus gen. nov.: G. cockingi sp. nov., G. cordatus sp. nov., G. currani sp. nov., G. longulus sp. nov., G. minutus sp. nov., G. vixsulcatus sp. nov.; Hesperanillus gen. nov.: H. bicostatus sp. nov., $H$. laticollis sp. nov., H. scanloni sp. nov.; Externalillus gen. nov.; E. mcraeae sp. nov.; Angustanillus gen. nov.: A. striatipennis sp. nov. The new species were detected in the course of surveys for the subterranean fauna in mining areas and were collected using two techniques: scraping and trapping. All species are blind and depigmented, character states which usually are connected with subterranean or cavicolous habits. Keys are provided for the genera of the Australian Anillina and for the species of Macranillus, Gracilanillus, and Hesperanillus. Some considerations about relationships of the new genera and species are presented.
\end{abstract}

KEYWORDS: taxonomy, new species, Western Australia, Angustanillus, Externalillus, Gracilanillus, Hesperanillus, Macranillus, Pilbaranillus

urn:Isid:zoobank.org:pub:D77452F3-C569-4FF9-A3F0-2FEBDFDE9490

\section{INTRODUCTION}

This is one of three papers describing carabid beetles collected by Bennelongia Environmental Consultants during surveys of mining areas in the Pilbara (mostly) and Yilgarn regions of Western Australia (see Baehr 2014a,b). All specimens were collected either by scraping or trapping. Both techniques are used to collect invertebrates from drill holes in the ground in iron ore mining areas as described by Halse \& Pearson (2014). All carabid species in the drill holes consist of more or less depigmented specimens with small eyes or even without visible eyes. They include species from the tribes Physocrotaphini (Baehr 2014a), Zuphiini (Baehr 2014b), and Bembidiini, subtribe Anillina. In this paper six new genera and 17 new species of Anillina are described. The taxonomic part has been written by the first author (MB), information about sampling methods and the maps have been added by the second author $(\mathrm{DM})$.

The material was transferred to Germany courtesy of Kym Abrams, Nadine Guthrie, Brian Hanich, and Nikolai Tatarnic (Perth).

\section{METHODS}

Standard methods were employed in the taxonomic investigations. The genitalia were removed and cleaned for a short while in hot $10 \% \mathrm{KOH}$. Since the specimens were very fragile, because they were preserved in $100 \%$ ethanol for future DNA extraction, the habitus is figured by drawing rather than by photographing and the female genitalia were not extracted in all species. 
Measurements were taken using a stereo microscope with an ocular micrometer. Length was measured from apex of labrum to apex of elytra. Length of pronotum was measured in a straight line from the apex of the anterior angles to the most produced part of the base. Length of the elytra was measured from the most advanced part of the humerus to the very apex.

The types of the new species are stored in the Western Australian Museum, Perth (WAM), some paratypes are in the working collection of the author at Zoologische Staatssammlung München (CBM).

\section{COLLECTING METHODS}

Halse \& Pearson (2014) provide extensive descriptions of two methods of sampling subterranean, but not cavicolous, animals deep below the ground surface: scraping and trapping. These methods were employed during surveys carried out in iron ore mining areas in arid parts of Western Australia. Scraping involved lowering a weighted net to the bottom of the drill hole and then pulling it back to the surface with the net scraping the walls of the hole. Some of the invertebrates on the walls were scraped into the net and brought to the surface. Trapping involved lowering one or two PVC tubes into the bore and leaving them in place for eight weeks after which they were brought back to the surface. The PVC tubes were baited with leaf litter and had occasional perforations to allow troglofauna into the tube to colonise the litter. The carabid species collected in traps and described in the present paper were caught at depths of 8 to at least $58 \mathrm{~m}$ below surface level. Most Anillina species were collected by trapping.

\section{SYTEMATICS}

\section{Family Carabidae}

Tribe Bembidiini

\section{Subtribe Anillina}

\section{TYPE GENUS}

Anillus Jacqelin Du Val, 1851

\section{REMARKS}

Anillina is a fairly large and diverse subtribe of Bembidiini, covering very small, microphthalmous or, more commonly, blind endogeous or cavicolous species that are characterised by depigmented surface, commonly absence of most or all elytral striae, sparse pilosity of the surface and short antenna (Jeannel 1937, 1963, Lorenz 2005, Giachino 2005). The systematic status of Anillina is somewhat uncertain and some authors render them a separate tribe, for example within the subfamily Trechinae (Moravec, Uéno \& Belousov 2003).
Anillina occur worldwide but, perhaps because of their small size and secretive habits, they are still most numerous and best known in southern Europe. For Australia, Giachino (2005) remarkably increased the number of species from 2 (see Moore et al. 1987) to 35 in his revision of the material available in the various Australian and fewer extra-Australian collections. This paper impressively demonstrated that appropriate collecting methods may considerably raise the knowledge about these tiny beetles.

To date, there are still 35 species recorded from Australia in four genera (Illaphanus Macleay, 1865; Pseudillaphanus Giachino, 2005; Tasmanillus Giachino, 2005; and Austranillus Giachino, 2005), of which Illaphanus is by far the largest genus in terms of species. Until now Anillina have been recorded only from the eastern and south-eastern parts of Australia, including Tasmania, and no species have been found in Western Australia. All recorded species have been collected from litter in rain and sclerophyll forest. Therefore, the species described in the present paper not only enlarge the range of the group to Western Australia, but they also demonstrate the occurrence of the group deep in the ground in semiarid habitats and, thus, significantly extend our knowledge about their ecology.

Apart from their occurrence in forest litter, nothing is known about the ecology and ethology of Australian Anillina. The success of subterranean sampling in collecting the group in Western Australia suggests similar sampling methods elsewhere may collect more Anillina and further extend our knowledge of the group.

Characteristics of the already recorded Australian species are: very small size, depressed body shape, depigmented, pilose surface; absence of eyes; unistriate or estriate elytra; common presence of an elongate sulcus running down at the middle of the elytra; absence of metathoracic wings; short legs; not denticulate tarsi; the aedeagus usually bearing a more or less sclerotised sclerite in the internal sac; triagonal parameres, usually with 2 apical setae. Female genitalia have not yet been recorded from Australian species.

Three of the genera described as new in the present paper deviate in having decidedly larger body size of all species; one of these possesses several distinct elytral striae; another new genus is characterised by very narrow and elongate, parallel elytra; and three new genera completely lack the elytral sulcus.

A key to all Australian genera of Anillina is presented here to facilitate identifications. It replaces the key in Giachino (2005) and includes the new Western Australian genera. 


\section{KEY TO THE AUSTRALIAN GENERA OF ANILLINA}

1. Elytra with four distinct striae; both, pronotum and elytra, very elongate, ratio width/length of pronotum 0.86 , ratio length/width of elytra $>2.20$ (Figure 17); surface of pronotum and elytra with distinct, deep and large punctures; north-western Western Australia: Pilbara

Angustanillus gen. nov.

Elytra with at most a faint parasutural stria; pronotum and elytra less elongate, ratio width/ length of pronotum $>0.97$, ratio length/width of elytra $<2.15$; surface of pronotum without or with less deep and large punctures 2

2. Elytra with a distinct longitudinal sulcus extending between the scutellary puncture and the 9th puncture of the marginal series (Figures 1, 7) (in one species from Western Australia only visible in basal third) 3

Elytra without longitudinal sulcus 5

3. Body size large, always $>2 \mathrm{~mm}$; base of elytra wide, humerus almost rectangular; elytra with three discal punctures (Figures 1-5); north-western Western Australia: Pilbara Macranillus gen. nov.

Body size smaller, $<1.75 \mathrm{~mm}$ (usually much less); base of elytra and humerus variously shaped; elytra with at most two discal punctures ... 4

4. Elytra more or less oval-shaped, decidedly narrowed to base, humerus oblique or rounded; prothorax markedly cordiform; eastern Australia

Illaphanus Macleay, 1865

Elytra parallel-sided or almost so, little or not narrowed to base, humerus almost rectangular; prothorax usually rather quadrate (Figures 7-12); north-western Western Australia: Pilbara Gracilanillus gen nov.

5. Body size large, $>2.4 \mathrm{~mm}$ and pronotum almost as long as wide and base much wider than apex and humerus oblique-convex (Figure 6); apex of aedeagus slightly bent down (Figure 22); north-western Western Australia: Pilbara

Pilbaranillus gen. nov.

Body size smaller, $<1.8 \mathrm{~mm}$; either pronotum rather quadrate with base about as wide as apex, and with elongate elytra with almost rectangular humerus; or pronotum cordiform with much narrower base than apex, and with more or less oval-shaped elytra with oblique or rounded humerus; apex of aedeagus not bent down (Figures 23-24)
6. Pronotum not cordiform, base as wide as apex; elytra elongate with almost rectangular humerus; south-eastern New South Wales Austranillus Giachino, 2005

Pronotum decidedly cordiform, base considerably narrower than apex; elytra more or less ovalshaped or with oblique-convex humerus (Figures 13-16)

7. Elytra with an additional marginal puncture, situated slightly inside of 2 nd marginal puncture and elytra distinctly oval-shaped and with obliqueconvex humerus; Tasmania

Tasmanillus Giachino, 2005

Elytra without an additional marginal puncture; elytra oval shaped or not; not in Tasmania ....... 8

8. Body size smaller, length $<1.26 \mathrm{~mm}$; pronotum very wide, ratio width/length $>1.35$; elytra shorter, ratio length/width $<1.55$; eastern New South Wales, south-eastern Queensland

Pseudillaphanus Giachino, 2005

Body size larger, length $>1.35 \mathrm{~mm}$; pronotum usually narrower; when ratio width/length $>1.30$, body size larger, length c. $1.50 \mathrm{~mm}$, and elytra longer, ratio length/width 1.75; elytra longer, ratio length/width $>1.65$ (Figures 13-16); north-western and interior southern Western Australia 9

9. Body size larger, length $>1.50 \mathrm{~mm}$; eye area markedly prominent, head almost as wide as pronotum; pronotum wider, ratio width/length $>1.18$ (Figures 13-15); north-western Western Australia: Pilbara ........... Hesperanillus gen. nov.

Body size smaller, length $1.35 \mathrm{~mm}$; eye area not prominent, head decidedly narrower than pronotum; pronotum narrower, ratio width/ length 1.05 (Figure 16); interior southern Western Australia Externanillus gen. nov.

\section{Genus Macranillus gen. nov.}

urn:Isid:zoobank.org:act:1FF99B26-903E-4123-9F0CAFCB7BDBE756

\section{TYPE SPECIES}

Macranillus bennetti sp. nov., by present designation.

\section{DIAGNOSIS}

Body size large (in group). Colour depigmented, yellow to rusty red. Surface with distinct, on pronotum and particularly on elytra, commonly coarse and rough, isodiametric to slightly transverse microreticulation, rather sparsely pubescent. 
Head large, slightly narrower than pronotum. Eye absent, head laterally convex. Mandibles short. Maxillary palpus short, preapical palpomere globose, densely pilose, apical palpomere tiny, barely recognisable. Labial palpus small, labium transverse. Mentum not fused to submentum, mental tooth absent. Two supraorbital seta and one clypeal seta present, usually also one seta on frons and another inside the posterior supraorbital seta present. Antenna short, more or less globose.

Pronotum rather quadrate, rarely slightly concave near basal angle. Apical angle not or slightly produced, basal angle angulate. Lateral margin faintly denticulate just in front of the basal angle. Margin bisetose.

Elytra elongate and parallel-sided, wide at base. Humerus obtusely rectangular, base more or less transversal. Lateral margin almost straight, apex rounded, not emarginated, nor transverse. Surface depressed, striae absent, but with an elongate, shallow, wide sulcus running slightly oblique from near scutellary puncture to position of 9th marginal puncture. Lateral margin coarsely denticulate, at least in basal half, and pilose; scutellary puncture present but usually difficult to detect within the coarse microsculpture; 3 discal punctures present but barely discernible. Microreticulation usually coarse, isodiametric to slightly transverse. Surface rather sparsely pilose.

Metathoracic wings absent.

Legs short, profemur not dentate. 1st and 2nd tarsomeres of male protarsus little dilated, sparsely pilose.

Lower surface microreticulate and sparsely pilose.

Aedeagus rather similar in all species: fairly elongate, markedly curved, with short, rather obtuse apex. Internal sac with two or three, rarely only one, narrow, more or less strongly sclerotised pieces. Parameres differently shaped, right paramere very slender, both with two elongate apical setae.

Gonocoxite 2 elongate, curved, acute, usually with one dorso-median and one ventro-lateral ensiform seta, and with an elongate subapical nematiform seta.

\section{DISTRIBUTION}

So far five species have been recorded from the Pilbara, north-western Australia. All have been collected from drill holes in mining areas at depths between 8 and $29 \mathrm{~m}$. Nothing is known about habits, diet, and reproduction.

\section{RELATIONSHIPS}

Together with Pilbaranillus and Angustanillus this genus is outstanding within Australian Anillina due to its large body size. It may be related to Pilbaranillus, but probably even more to Gracilanillus, mainly by virtue of presence of the elytral sulcus and fairly similar shape of pronotum and elytra.

\section{ETYMOLOGY}

The name refers to the large body size of all species.

\section{Macranillus bennetti sp. nov.}

Figures 1, 18

urn:Isid:zoobank.org:act:19472306-9B51-47A7-8C8C9B16DD369838

\section{MATERIAL EXAMINED}

\section{Holotype}

Australia: Western Australia: $\mathrm{O}^{\lambda}$, c. $60 \mathrm{~km}$ WNW. Wittenoom $22^{\circ} 07^{\prime} 44.10^{\prime \prime S} 117^{\circ} 45^{\prime} 51.00^{\prime \prime E ~(W G S ~ 84) ~}$ 03 Mar. 2012-02 May 2012 J.S. Cocking, S.R. Bennett (SM0653) Trog trap, $9 \mathrm{~m} /$ BINSECT0019 (WAM E84014)

\section{Paratypes}

Australia: Western Australia: 3 o, 2 , same data

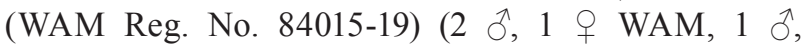
CBM); 1 $\hat{\jmath}, 1$, Solomon, c. $62 \mathrm{~km}$ WNW. Wittenoom 22 07'13.50"S 11744'54.60"E (WGS 84) 13 Sep. 2012 J.S. Cocking, S.R. Bennett (SM1573) Trog scrape, 8 m / BINSECT0020 (WAM E84020-21, 1 q CBM).

\section{DIAGNOSIS}

Large, elongate, depressed, parallel-sided, rufous species with quadrate pronotum and elongate, parallelsided elytra; distinguished from other species by shape of pronotum, very coarse microreticulation of pronotum and elytra, and in apical part markedly widened aedeagus.

\section{DESCRIPTION}

Measurements: Length: 2.15-2.4 mm; width: 0.72$0.84 \mathrm{~mm}$. Ratio width/length of pronotum: 1.16-1.18; width of base/width of apex of pronotum: 1.19-1.21; ratio length/width of elytra: 1.73-1.77; ratio length/width of 10th antennomere: 1.2.

Colour: Upper and lower surfaces more or less pale red, palpi, antenna, and legs dark yellow.

Head (Figure 1): Distinctly narrower than pronotum, short and wide, laterally convex. Upper surface gently convex. Frons with an inconspicuous, oblique and curved sulcus on either side just behind the clypeal suture. Neck wide. Clypeus bisetose, setae elongate. Labrum straight at apex, 6-setose. Subapical palpomere of maxillary palpus relatively narrow, apical palpomere tiny, barely visible. Antenna short, median antennomeres globose, c. $1.2 \mathrm{x}$ as long as wide. Frons with an elongate seta at either side, another elongate seta inside of posterior supraorbital seta. Surface sparsely 
pilose, pilosity short and inclined slightly anteriad, only laterally pilosity slightly denser. Microreticulation rather fine, isodiametric.

Prothorax (Figure 1): Quadrate, comparatively wide, wider than long, widest at about apical third. Apical margin straight, apical angle very slightly produced; lateral margin apart from apical fourth very gently convex, immediately in front of the sharply angulate basal angle with a tiny, obtuse protuberance. Base wide, very faintly concave. Apex and base not margined, lateral margin narrow, not widened basad. Disk depressed. Median line fine, slightly impressed, ending far from apex and base. No transverse sulci visible. Basal grooves very shallow, rounded. Anterior marginal seta situated about at apical fourth, posterior seta located at basal angle. Surface with very sparse, short, slightly declined pilosity. Microreticulation coarse and distinct, isodiametric.

Elytra (Figure 1): Elongate, parallel, disk rather depressed. Humerus obtusely angulate, base slightly oblique. Lateral margin straight, pilose, at least in anterior half coarsely denticulate. Apex convex. No striae perceptible. Discal sulcus shallow and wide. Microreticulation coarse, isodiametric to slightly transverse, therefore marginal and discal punctures diffcult to distinguish when setae are broken. Disk with three discal punctures and setae, at basal third, apical third, and close to apex. Marginal setae very elongate. Metathoracic wings absent.

Lower surface: Coarsely microreticulate and sparsely pilose. Metepisternum rather elongate, c. $1.5 \mathrm{x}$ as long as wide at apex. Terminal sternum in male bisetose, in female quadrisetose.

Legs: Short, densely pilose. In male two basal tarsomeres protarsus barely widened and sparsely pilose underneath.

Male genitalia (Figure 18): Aedeagus fairly elongate, moderately wide, but in apical part distinctly widened at the right side; lower surface moderately concave. Apex acute, triangular. Internal sac with three narrow, slightly sclerotised pieces. Left paramere large, triangular, right paramere very slender, both bisetose, but the upper seta on the left paramere longer than the lower one.

Female gonocoxites: Much as in M. magnus sp. nov.

Variation: Very little variation noted. The two specimens collected by scraping are slightly smaller, but the aedeagus of the single male is very similar to that of the specimens collected by trapping.

\section{COLLECTING CIRCUMSTANCES}

Collected up to $9 \mathrm{~m}$ below ground surface.

\section{DISTRIBUTION}

Near Wittenoom, Pilbara, north-western Western Australia, known only from a very restricted area.

\section{RELATIONSHIPS}

With respect to body size and shape most similar to M. pearsoni sp. nov. and M. maini sp. nov., but well distinguished from the first by shape of aedeagus, and from the second by decidedly shorter elytra and wider base of pronotum.

\section{ETYMOLOGY}

The name is a patronym in honour of Sean Bennett, one of the collectors.

\section{Macranillus pearsoni sp. nov.}

Figures 2, 19

urn:Isid:zoobank.org:act:A9D589BD-BA08-46C8-B692AACOBEAAFE28

\section{MATERIAL EXAMINED}

\section{Holotype}

Australia: Western Australia: ${ }^{2}$, Flinders Mine, 73 $\mathrm{km}$ NNW. Tom Price $22^{\circ} 08^{\prime} 14.60^{\prime \prime S} 117^{\circ} 25^{\prime} 28.60^{\prime \prime E}$ (WGS 84) 07 Feb. 2012 J.S. Cocking, G.B. Pearson (HPRC0930) Trog scrape, $17 \mathrm{~m} /$ BINSECT0021 (WAM E84022).

\section{Paratype}

Australia: Western Australia: ${ }^{\circ}$, same data (WAM E84023).

\section{DIAGNOSIS}

Large, elongate, depressed, parallel-sided, pale red species with moderately elongate, somewhat quadrate pronotum and comparatively short, parallel-sided elytra; distinguished from other species by relatively narrow base of pronotum, less strongly serrate elytral margin, coarse microreticulation of the dorsal surface, particularly of the elytra, and not widened apex of aedeagus.

\section{DESCRIPTION}

Measurements: Length: $2.25-2.3 \mathrm{~mm}$; width: $0.75-$ $0.78 \mathrm{~mm}$. Ratio width/length of pronotum: 1.15-1.17; width of base/width of apex of pronotum: 1.10-1.14; ratio length/width of elytra: 1.65-1.70; ratio length/width of 10th antennomere: 1.2 .

Colour: Upper and lower surfaces more or less pale red, palpi, antenna, and legs slightly paler.

Head (Figure 2): Distinctly narrower than pronotum, short and wide, laterally convex. Upper surface gently convex. Frons with an inconspicuous, oblique and slightly curved sulcus on either side just behind the clypeal suture. Neck wide. Clypeus bisetose, setae elongate. Labrum straight at apex, 6-setose. Subapical palpomere of maxillary palpus relatively narrow, apical 
palpomere tiny, barely perceptible. Antenna short, median antennomeres globose, c. $1.2 \mathrm{x}$ as long as wide. Frons with an elongate seta at either side, another elongate seta inside of posterior supraorbital seta. Surface very sparsely pilose, pilosity short and inclined slightly anteriad, only laterally pilosity slightly denser. Microreticulation moderately coarse, about isodiametric.

Prothorax (Figure 2): Somewhat quadrate, comparatively elongate, considerably wider than long, widest at apical third. Apical margin straight, apical angle very slightly produced; lateral margin apart from apical fourth very gently convex, immediately in front of the rectangular or even slightly denticulate basal angle with a short, obtuse protuberance. Base comparatively narrow but yet wider than apex, straight. Apex and base not margined, lateral margin narrow, not widened basad. Disk depressed. Median line fine, slightly impressed, ending far from apex and base. No transverse sulci visible. Basal grooves shallow, linear. Anterior marginal seta situated slightly in front of apical fourth, posterior seta situated just in front of basal angle, setae elongate. Surface with very sparse, short, slightly declined pilosity. Microreticulation coarse and distinct, about isodiametric.

Elytra (Figure 2): Rather elongate, almost parallelsided, disk rather depressed, wide at humerus. Humerus obtusely angulate, base slightly oblique. Lateral margin straight, pilose, at least in anterior half fairly coarsely denticulate. Apex convex. No striae perceptible. Discal sulcus shallow but wide. Microreticulation coarse, isodiametric to slightly transverse, surface sparsely pilose. Three discal punctures and setae perceptible, at basal third, apical third, and close to apex. Marginal setae very elongate. Metathoracic wings absent.

Lower surface: Coarsely microreticulate and very sparsely pilose. Metepisternum rather elongate, c. 1.5 $\mathrm{x}$ as long as wide at apex. Terminal sternum in male bisetose, in female quadrisetose.

Legs: Short, densely pilose. In male two basal tarsomeres protarsus barely widened and sparsely pilose underneath.

Male genitalia (Figure 19): Aedeagus fairly elongate, rather slender; lower surface in basal part extremely concave. Apex acute, triangular. Internal sac with two narrow, moderately sclerotised pieces. Left paramere large, triangular, right paramere slender, both bisetose, but the upper seta on the left paramere much longer than the lower one.

Female gonocoxites: Much as in M. magnus sp. nov.

Variation: Slight variation noted in length of the elytra and relative width of the base of the pronotum.

\section{COLLECTING CIRCUMSTANCES}

Collected at an unknown depth $(<17 \mathrm{~m})$ below surface.

\section{DISTRIBUTION}

Near Tom Price, central Pilbara, north-western Western Australia, known only from type locality.

\section{RELATIONSHIPS}

This is a well characterised species based on the rather short elytra and the shape of the pronotum and aedeagus.

\section{ETYMOLOGY}

The name is a patronym in honour of Grant Pearson, one of the collectors.

\section{Macranillus maini sp. nov.}

Figure 3

urn:Isid:zoobank.org:act:990038BE-92D8-4330-BAD08E7D9FC023A1

\section{MATERIAL EXAMINED}

Holotype

Australia: Western Australia: ${ }^{+}$, Flinders Mine, $67 \mathrm{~km}$ NNW. Tom Price 2210'31.70"S 117²2'10.00"E (WGS 84) 27 Jul. 2011-26 Sep. 2011 J.S. Cocking, D.C. Main (HPRC0105) Trog trap, $21 \mathrm{~m} /$ BINSECT0022 (WAM E84024).

\section{Paratype}

Australia: Western Australia: + , same data (WAM E84025).

\section{DIAGNOSIS}

Large, elongate, depressed, parallel-sided, rufous species with rather wide, quadrate pronotum and elongate, parallel elytra; distinguished from other species, particularly the most similar M. pearsoni sp. nov. by decidedly longer elytra and wider pronotum.

\section{DESCRIPTION}

Measurements: Length: 2.2-2.4 mm; width: 0.75-0.8 $\mathrm{mm}$. Ratio width/length of pronotum: 1.18-1.22; width of base/width of apex of pronotum: 1.12-1.14; ratio length/width of elytra: $1.80-1.81$; ratio length/width of 10th antennomere: 1.2 .

Colour: Upper and lower surfaces pale red, palpi, antenna, and legs slightly paler.

Head (Figure 3): Perceptibly narrower than pronotum, short and wide, laterally convex. Upper surface gently convex. Frons with an inconspicuous, oblique and curved sulcus on either side just behind the clypeal suture. Neck wide. Clypeus bisetose, setae elongate. Labrum straight at apex, 6-setose. Subapical palpomere of maxillary palpus relatively narrow, apical palpomere tiny, barely perceptible. Antenna 
short, median antennomeres globose, c. $1.2 \mathrm{x}$ as long as wide. Frons with an elongate seta at either side, another elongate seta inside of posterior supraorbital seta. Surface sparsely pilose, pilosity short and inclined slightly anteriad, only laterally pilosity slightly denser. Microreticulation moderately coarse, about isodiametric.

Prothorax (Figure 3): Quadrate, comparatively wide, considerably wider than long, widest behind apical third. Apical margin straight, apical angle slightly but distinctly produced; lateral margin apart from apical fourth very gently convex, immediately in front of the rectangular basal angle with a tiny, obtuse protuberance. Base moderately wide, straight. Apex and base not margined, lateral margin narrow, not widened basad. Disk depressed. Median line fine, slightly impressed, ending far from apex and base. Anterior transverse sulcus not visible, posterior transverse sulcus faint, barely impressed. Basal grooves shallow, slightly circular. Anterior marginal seta situated slightly behind apical fourth, posterior seta located at basal angle, setae elongate. Surface with sparse, short, slightly declined pilosity. Microreticulation coarse and distinct, about isodiametric.

Elytra (Figure 3): Comparatively elongate, parallelsided, disk rather depressed. Humerus obtusely angulate, base slightly oblique. Lateral margin straight, pilose, in anterior half coarsely, in posterior half only indistinctly denticulate. Apex convex. No striae perceptible. Discal sulcus shallow but wide. Microreticulation coarse, isodiametric to slightly transverse, surface sparsely pilose. Three discal punctures and setae barely perceptible within the coarse microsculpture, at basal third, apical third, and close to apex. Marginal setae very elongate. Metathoracic wings absent.

Lower surface: Coarsely microreticulate and sparsely pilose. Metepisternum rather elongate, c. 1.5 $\mathrm{x}$ as long as wide at apex. Terminal sternum in female quadrisetose.

Legs: Short, densely pilose. Male protarsus unknown.

Male genitalia. Unknown.

Female gonocoxites: Much as in M. magnus sp. nov.

Variation: Apart from body size very little variation noted.

\section{COLLECTING CIRCUMSTANCES}

Collected in a troglofauna trap set $21 \mathrm{~m}$ below ground surface.

\section{DISTRIBUTION}

Near Tom Price, central Pilbara, north-western Western Australia, known only from type locality.

\section{RELATIONSHIPS}

With respect to body shape most similar to $M$. bennetti sp. nov. and M. pearsoni sp. nov. Males are required for comparison of the aedeagi.

\section{ETYMOLOGY}

The name is a patronym in honour of Dean Main, one of the collectors.

\section{Macranillus magnus sp. nov.}

Figures 4, 20, 25

urn:Isid:zoobank.org:act:3CB4C617-0539-4120-8AA23B871323FC6C

\section{MATERIAL EXAMINED}

\section{Holotype}

Australia: Western Australia: ${ }^{\lambda}$, Solomon, c. $35 \mathrm{~km}$ W Wittenoom 22¹1'51.1"S 11758'12.4"E (WGS 84) 04 Sep. 2011 S.R. Bennett, J.S. Cocking (SM0267.02) Scrape, 17 m (WAM E84108).

\section{Paratype}

Australia: Western Australia: + , Solomon, c. $35 \mathrm{~km}$ W Wittenoom $22^{\circ} 11^{\prime} 44.5^{\prime \prime S} 117^{\circ} 57^{\prime} 58.5^{\prime \prime} \mathrm{E}$ (WGS 84) 04 Sep. 2011 S.R. Bennett, J.S. Cocking (SM0250.01) Scrape, 29 m (WAM E84107).

\section{DIAGNOSIS}

Very large, elongate, depressed, parallel-sided, rufous species with comparatively elongate, quadrate pronotum and elongate, parallel sided elytra; distinguished from other species by larger body size, relatively dark colour, shape of pronotum, very coarse microreticulation of the dorsal surface, particularly on the elytra, and narrow aedeagus with very concave lower surface.

\section{DESCRIPTION}

Measurements: Length: 2.8-2.85 mm; width: 0.87$0.92 \mathrm{~mm}$. Ratio width/length of pronotum: 1.08-1.09; width of base/width of apex of pronotum: 1.19-1.21; ratio length/width of elytra: 1.77-1.78; ratio length/ width of 10th antennomere: 1.3.

Colour: Upper and lower surfaces rusty red, palpi, antenna, and legs slightly paler.

Head (Figure 4): Perceptibly narrower than pronotum, short and wide, laterally convex. Upper surface gently convex. Frons with an inconspicuous, oblique and curved sulcus on either side just behind the clypeal suture. Neck wide. Clypeus bisetose, setae elongate. Labrum straight at apex, 6-setose. Subapical palpomere of maxillary palpus relatively narrow, apical palpomere tiny, barely perceptible. Antenna short, median antennomeres globose, c. $1.3 \mathrm{x}$ as long as wide. Frons with an elongate seta at either side, another elongate seta inside of posterior supraorbital seta. 
Surface very sparsely pilose, pilosity short and inclined slightly anteriad, only laterally pilosity slightly denser. Microreticulation coarse, about isodiametric.

Prothorax (Figure 4): Quadrate, comparatively elongate, but slightly wider than long, widest at apical fourth or third. Apical margin straight, apical angle very slightly produced; lateral margin apart from apical fourth very gently convex, immediately in front of the rectangular, slightly denticulate basal angle with a short, obtuse protuberance. Base wide, almost straight, even very faintly concave. Apex and base not margined, lateral margin narrow, not widened basad. Disk depressed. Median line fine, slightly impressed, ending far from apex and base. No transverse sulci visible. Basal grooves shallow, about linear. Anterior marginal seta situated slightly in front of apical fourth, seta elongate; posterior seta not visible. Surface with very sparse, short, slightly declined pilosity. Microreticulation coarse and distinct, about isodiametric.

Elytra (Figure 4): Elongate, parallel, disk rather depressed, wide at humerus. Humerus obtusely angulate, base slightly oblique. Lateral margin straight, pilose, at least in anterior half coarsely denticulate. Apex convex. No striae perceptible. Discal sulcus shallow but wide. Microreticulation very coarse, isodiametric to slightly transverse, therefore marginal and discal punctures barely perceptible when setae are broken; surface sparsely pilose. Disk with three discal punctures and setae, at basal third, apical third, and close to apex. Marginal setae very elongate. Metathoracic wings absent.

Lower surface: Coarsely microreticulate and very sparsely pilose. Metepisternum rather elongate, c. 1.5 $\mathrm{x}$ as long as wide at apex. Terminal sternum in male bisetose, in female quadrisetose.

Legs: Short, densely pilose. In male two basal tarsomeres of protarsus barely widened and sparsely pilose underneath.

Male genitalia (Figure 20): Aedeagus fairly elongate, rather slender; lower surface in basal part very concave. Apex acute, triangular. Internal sac with three narrow, more or less sclerotised pieces. Left paramere large, triangular, right paramere slender, both bisetose, but the upper seta on the left paramere much longer than the lower one.

Female gonocoxites (Figure 25): Gonocoxite 1 compact, without setae at the apical margin. Gonocoxite 2 elongate, curved, with acute apex, with one dorsomedian ensiform seta in apical fourth, one fairly elongate ventro-lateral ensiform seta about at middle, and an elongate nematiform seta near apex that originates in a pit.

Variation: Very little variation noted.

\section{COLLECTING CIRCUMSTANCES}

Collected by scraping at unknown depths up to $17 \mathrm{~m}$ and $29 \mathrm{~m}$ below surface.

\section{DISTRIBUTION}

Near Wittenoom, northern Pilbara, north-western Western Australia, known only from two localities very close to each other.

\section{RELATIONSHIPS}

The large body size and the rather elongate pronotum make M. magnus sp. nov. an easily distinguished species.

\section{ETYMOLOGY}

The name refers to the exceptionally large body size of this species.

\section{Macranillus quartermainei sp. nov.}

Figures 5, 21

urn:Isid:zoobank.org:act:0C0791DA-EFAA-4B3C-8470D157AE50299D

\section{MATERIAL EXAMINED}

Holotype

Australia: Western Australia: ${ }^{\lambda}$, Western Hub, c. 91 km SSE. Pannawonica 22॰19'29.40"S 116 $49^{\prime} 02.90^{\prime \prime E}$ (WGS 84) 01 May 2013-04 Jul. 2013 J.W. Quartermaine, S.R. Bennett (DL0414) Trog trap, $20 \mathrm{~m} /$ BINSECT0029 (WAM E84032)

\section{Paratypes}

Australia: Western Australia: 4 , same data (WAM E84033-36) (3 WAM, 1 CBM).

\section{DIAGNOSIS}

Large, elongate, depressed, parallel-sided, rufous species with slightly cordiform pronotum and elongate. parallel-sided elytra; distinguished from other species by slightly concave lateral margin and narrower base of pronotum, very coarse microreticulation of the dorsal surface, particularly on the elytra, and compact but narrow aedeagus.

\section{DESCRIPTION}

Measurements: Length: $2.0-2.45 \mathrm{~mm}$; width: $0.69-$ $0.82 \mathrm{~mm}$. Ratio width/length of pronotum: 1.17-1.21; width of base/width of apex of pronotum: 1.05-1.07; ratio length/width of elytra: $1.75-1.78$; ratio length/width of 10th antennomere: 1.2.

Colour: Upper and lower surfaces more or less rusty red, palpi, antenna, and legs slightly paler.

Head (Figure 5): Distinctly narrower than pronotum, short and wide, laterally convex. Upper surface gently convex. Frons with an inconspicuous, oblique and curved sulcus on either side just behind the clypeal suture. Neck wide. Clypeus bisetose, setae elongate. Labrum straight at apex, 6-setose. Subapical palpomere of maxillary palpus relatively narrow, 
apical palpomere tiny, barely perceptible. Antenna short, median antennomeres globose, c. $1.2 \mathrm{x}$ as long as wide. Frons with an elongate seta at either side, but without seta inside of posterior supraorbital seta. Surface very sparsely pilose, pilosity short and slightly inclined anteriad, only laterally pilosity slightly denser. Microreticulation coarse, about isodiametric.

Prothorax (Figure 5): Moderately wide, distinctly wider than long, widest at apical fourth. Apical margin straight, apical angle not produced; lateral margin apart from apical fourth oblique, straight to slightly concave, in front of the rectangular basal angle finely serrulate. Base comparatively narrow, little wider than apex, almost straight, laterally even very faintly concave. Apex and base not margined, lateral margin narrow, not widened basad. Disk depressed. Median line fine, slightly impressed, ending far from apex and base. Anterior transverse sulcus not visible, posterior sulcus distinct, slightly impressed, curved. Basal grooves shallow. Anterior marginal seta situated slightly in front of apical fourth, posterior seta situated just in front of basal angle, setae elongate. Surface with sparse, short, slightly declined pilosity. Microreticulation coarse and distinct, slightly transverse.

Elytra (Figure 5): Elongate, parallel-sided, disk rather depressed, wide at humerus. Humerus shortly rounded, base transverse. Lateral margin straight, pilose, at least in anterior half coarsely denticulate. Apex convex. No striae perceptible. Discal sulcus shallow but wide. Microreticulation very coarse, slightly transverse, therefore marginal and discal punctures barely perceptible when setae are broken; surface sparsely pilose. Three discal punctures and setae present, at basal third, apical third, and close to apex, but all setae broken. Marginal setae very elongate. Metathoracic wings absent.

Lower surface: Coarsely microreticulate and very sparsely pilose. Metepisternum rather elongate, c. 1.5 $\mathrm{x}$ as long as wide at apex. Terminal sternum in male bisetose, in female quadrisetose.

Legs: Short, densely pilose. In male two basal tarsomeres of protarsus barely widened and sparsely pilose underneath.

Male genitalia (Figure 21): Aedeagus fairly elongate, rather compact but slender; lower surface in basal part rather concave. Apex obtusely angulate, triangular. Internal sac with a narrow and a fairly wide, more or less sclerotised piece. Left paramere large, triangular, right paramere very slender, both bisetose, but the upper seta on the left paramere longer than the lower one.

Female gonocoxites: Much as in M. magnus sp. nov.

Variation: Apart from some differences in body size, little variation noted.

\section{COLLECTING CIRCUMSTANCES}

Collected in troglofauna trap set $20 \mathrm{~m}$ below ground surface.

\section{DISTRIBUTION}

South-east of Pannawonica, western Pilbara, northwestern Western Australia, known only from type locality.

\section{RELATIONSHIPS}

The shape of the pronotum enables $M$. quartermainei sp. nov. to be easilly distinguished.

\section{ETYMOLOGY}

The name is a patronym in honour of Jeremy Quartermaine, one of the collectors.

\section{Genus Pilbaranillus gen. nov.}

urn:Isid:zoobank.org:act:66263E93-11A8-477B-8FBED57AC038FE76

\section{TYPE SPECIES}

Pilbaranillus latibasis sp. nov., by monotypy.

\section{DIAGNOSIS}

Body size large (in group). Colour depigmented, dark yellow. Surface with inconspicuous, isodiametric to slightly transverse microreticulation, elytra with coarse punctation, surface rather sparsely pubescent.

Head large, slightly narrower than pronotum. Eye absent, head laterally convex. Mandibles short. Maxillary palpus short, preapical palpomere globose, densely pilose, apical palpomere tiny, barely recognisable. Labial palpus small, labium transverse. Mentum not fused to submentum, mental tooth absent. Two supraorbital seta and one clypeal seta present, also one seta on frons and another inside the posterior supraorbital seta. Antenna short, rather globose.

Pronotum comparatively elongate, rather quadrate, with remarkably wide basis as compared with the apex. Apical angle barely produced, basal angle angulate. Lateral margin faintly denticulate just in front of the basal angle. Margin bisetose.

Elytra moderately elongate, rather oval-shaped, narrowed basad. Humerus obliquely-convex, base slightly oblique. Lateral margin rather straight but slightly oblique, apex rounded, not emarginate. Surface depressed, striae absent, without discal sulcus. Lateral margin coarsely denticulate, at least in basal half, and pilose; scutellary puncture present but difficult to detect within the coarse punctation; 3 discal punctures present but barely discernible. Microreticulation superficial, slightly transverse. Surface rather sparsely pilose.

Metathoracic wings absent.

Legs short, profemur not dentate. 1st and 2nd tarsomeres of male protarsus slightly dilated and pilose.

Lower surface microreticulate and sparsely pilose.

Aedeagus fairly elongate, markedly curved, with short, rather obtuse apex. Internal sac with three narrow, 
sclerotised pieces. Parameres differently shaped, right very slender, both with two elongate apical setae.

Gonocoxites unknown.

\section{DISTRIBUTION}

A single species recorded from the western Pilbara, north-western Western Australia. Sampled by scraping in a drill hole $71 \mathrm{~m}$ deep. Nothing is known about habits, diet, and reproduction.

\section{RELATIONSHIPS}

This genus differs in some character states from the rather similarly sized and shaped species of the genus Macranillus, namely in the shorter, less parallel-sided elytra, more widely rounded humerus, absence of the elytral sulcus, weak microreticulation but strong punctation on the elytra, and slightly pointed down apex of the aedeagus.

\section{ETYMOLOGY}

The name refers to the occurrence of the single species in the Pilbara region.

\section{Pilbaranillus latibasis sp. nov.}

Figures 6, 22

urn:Isid:zoobank.org:act:E6481C65-6948-4763-8DC94D5E7E63252C

\section{MATERIAL EXAMINED}

\section{Holotype}

Australia: Western Australia: $\hat{\jmath}$, Dragon, c. $45 \mathrm{~km} \mathrm{~S}$. Pannawonica $22^{\circ} 00^{\prime} 45.0^{\prime \prime S} 116^{\circ} 33 ' 31.5^{\prime \prime E}$ (WGS 84) 19 Jul. 2012 G.B. Pearson, S.R. Bennett (RI011) Scrape, 71 m / BENN049 (WAM E84038).

\section{DIAGNOSIS}

Large, rather wide, depressed, flavous species with rather quadrate pronotum and wide, slightly oval-shaped elytra; distinguished from genera without elytral sulcus by much larger body size.

\section{DESCRIPTION}

Measurements: Length: $2.45 \mathrm{~mm}$; width: $0.9 \mathrm{~mm}$. Ratio width/length of pronotum: 1.02; width of base/ width of apex of pronotum: 1.25; ratio length/width of elytra: 1.64; ratio length/width of 10th antennomere: 1.3 .

Colour: Upper and lower surfaces pale red, palpi, antenna, and legs yellow.

Head (Figure 6): Distinctly narrower than pronotum, comparatively elongate, laterally convex. Upper surface gently convex. Frons with an inconspicuous, oblique and curved sulcus on either side just behind the clypeal suture. Neck wide. Clypeus bisetose, setae elongate. Labrum straight at apex, 6-setose. Subapical palpomere of maxillary palpus relatively narrow, apical palpomere tiny, barely perceptible. Antenna short, median antennomeres globose, c. $1.3 \mathrm{x}$ as long as wide. Frons with an elongate seta at either side, another elongate seta inside of posterior supraorbital seta. Surface very sparsely pilose, pilosity short and inclined slightly anteriad, only laterally pilosity slightly denser. Microreticulation rather superficial, about isodiametric to slightly transverse.

Prothorax (Figure 6): Quadrate, comparatively elongate, barely wider than long, widest at apical third. Apical margin almost straight, apical angle very slightly produced; lateral margin apart from apical fourth very gently convex to almost straight and slightly oblique, immediately in front of the almost rectangular, slightly denticulate basal angle with a short, obtuse protuberance. Base wide, much wider than apex, almost straight, laterally even very faintly concave. Apex and base not margined, lateral margin narrow, not widened basad. Disk depressed. Median line fine, slightly impressed, ending far from apex and base. Anterior transverse sulcus absent, posterior sulcus visible but faint. Basal grooves shallow. Anterior marginal seta situated slightly in front of apical third, seta elongate; posterior seta located close to basal angle. Surface with rather sparse, fairly elongate, almost erect pilosity. Microreticulation comparatively faint, rather transverse.

Elytra (Figure 6): Comparatively short and wide, not exactly parallel, disk gently convex, widest at basal fourth. Humerus rounded, base slightly oblique. Lateral margin behind basal third straight but faintly oblique, pilose, rather finely denticulate. Apex convex. No striae perceptible. Virtually no discal sulcus perceptible. Surface coarsely punctate, microreticulation superficial, slightly transverse, surface with comparatively dense and elongate, almost erect pilosity. Disk with three discal punctures and setae, at basal third, apical third, and close to apex, but punctures very difficult to see within the coarse punctation, because all setae are broken. Marginal setae very elongate. Metathoracic wings absent.

Lower surface: Rather coarsely microreticulate, sparsely pilose. Metepisternum fairly elongate, c. 1.5 $\mathrm{x}$ as long as wide at apex. Terminal sternum in male bisetose.

Legs: Short, densely pilose. In male two basal tarsomeres of protarsus barely widened, sparsely pilose underneath.

Male genitalia (Figure 22): Aedeagus fairly elongate, moderately wide; lower surface in basal part only moderately concave. Apex obtusely triangular but in lateral view slightly bent down. Internal sac with three narrow, more or less sclerotised pieces. Left paramere large, triangular, right paramere very slender, both bisetose, setae on both parameres of about same length.

Female gonocoxites: Unknown.

Variation: Unknown. 


\section{COLLECTING CIRCUMSTANCES}

The holotype was collected at unknown depth by scraping of a $71 \mathrm{~m}$ deep drill hole.

\section{DISTRIBUTION}

Near Pannawonica, western Pilbara, north-western Western Australia, known only from type locality.

\section{ETYMOLOGY}

The name refers to the wide basis of the pronotum as compared with the apex.

\section{Genus Gracilanillus gen. nov.}

\author{
urn:Isid:zoobank.org:act:EE316503-0DD9-4816-B179- \\ 685DF7C97137
}

\section{TYPE SPECIES}

Gracilanillus longulus sp. nov., by present designation.

\section{DIAGNOSIS}

Small to medium sized, depigmented, yellow to pale red species. Surface with inconspicuous, isodiametric to slightly transverse microreticulation, elytra with coarse punctuation and or microreticulation, surface rather sparsely pubescent.

Head large, usually barely narrower than pronotum. Eye absent, head laterally convex. Mandibles short. Maxillary palpus short, preapical palpomere globose, densely pilose, apical palpomere rather elongate. Labial palpus small, labium transverse. Mentum not fused to submentum, mental tooth present though faint. Two supraorbital seta and one clypeal seta present, also one seta on frons. Antenna short, rather globose.

Pronotum comparatively elongate, rather quadrate or almost so, rarely rather cordiform, usually with wide basis as compared with the apex. Apical angle barely produced, basal angle angulate. Lateral margin faintly denticulate just in front of the basal angle. Margin bisetose.

Elytra very narrow and elongate, markedly parallelsided, barely narrowed basad. Humerus angulate, almost rectangular, base almost transverse. Lateral margin straight over a long distance, apex rounded, not emarginated not transverse. Surface depressed, striae absent, with a weak discal sulcus that in some species is barely or only near base perceptible. Lateral margin rather coarsely denticulate, at least in basal half, and pilose; scutellary puncture present but difficult to detect within the coarse punctation; 3 discal punctures present but barely discernible. Microreticulation superficial, slightly transverse. Surface corsaley punctuate, rather sparsely pilose.

Metathoracic wings absent.

Legs short, profemur not dentate. 1st and 2 nd tarsomeres of male protarsus slightly dilated and pilose.
Lower surface microreticulate and sparsely pilose.

Aedeagus compact, in basal part markedly curved, with short, rather obtuse apex. Internal sac with one slightly more sclerotised piece. Parameres fairly differently shaped, right paramere slenderer than left, both with two elongate apical setae.

Gonocoxite 2 narrow and elongate, slightly curved, with acute apex, apparently without ensiform setae, with an elongate subapical nematiform seta.

\section{DISTRIBUTION}

Six species recorded from the Pilbara, north-western Western Australia. Sampled by scraping and trapping at depths up to $39 \mathrm{~m}$. Nothing is known about habits, diet, and reproduction.

\section{RELATIONSHIPS}

In some character states the genus is similar to Macranillus, particularly in the rather quadrate prothorax of most species, the parallel-sided elytra, and the almost rectangular humerus. It differs, however, by lesser body size, the very elongate elytra, and the chetotaxy of head and elytra. Gracilanillus differs strongly from eastern Illaphanus because of the narrow, elongate, and parallel body shape of the former. Therefore, Gracilanillus may be more related to Macranillus than to Illaphanus. Relationships to the genus Hesperanillus, or to certain species of that genus, are obscure, because the phylogenetic importance of the presence, or absence, of the elytral sulcus is uncertain. The weak formation of the sulcus in most species of Gracilanillus, however, suggests a minor phylogenetic value.

\section{ETYMOLOGY}

The name refers to the slender body shape of the very small species of this genus.

\section{Gracilanillus longulus sp. nov.}

Figure 7

urn:Isid:zoobank.org:act:A4852160-BCBF-41C1-B25D598C9DA027AB

\section{MATERIAL EXAMINED}

\section{Holotype}

Australia: Western Australia: $\widehat{~}$ (abdomen destroyed), West Pit, c. $45 \mathrm{~km} \mathrm{~S}$. Pannawonica 2159'17.7"S 116³0'01.1"E (WGS 84) 21 Jul. 2012 G.B. Pearson, S.R. Bennett (BS010) Scrape, 23 m / BENN050 (WAM E84039).

\section{DIAGNOSIS}

Moderately large (in genus), very narrow and elongate species with rather narrow pronotum and parallel-sided elytra; distinguished from similarly shaped species by 
combination of relatively narrow base of pronotum with comparatively obtuse basal angle, very elongate elytra, and relatively distinct elytral sulcus.

\section{DESCRIPTION}

Measurements: Length: $1.48 \mathrm{~mm}$; width: $0.36 \mathrm{~mm}$. Ratio width/length of pronotum: 0.97 ; width of base/ width of apex of pronotum: 0.88 ; ratio length/width of elytra: 2.14; ratio length/width of 10 th antennomere: 1.15 .

Colour: Upper and lower surfaces yellow, palpi, antenna, and legs pale yellow.

Head (Figure 7): Large, barely narrower than pronotum, wide, laterally convex. Eye area prominent. Upper surface gently convex. Frons with an inconspicuous, short, oblique sulcus on either side just behind the clypeal suture. Neck wide. Clypeus bisetose, setae elongate. Labrum slightly concave at apex, 6-setose. Subapical palpomere of both palpi compact and with elongate pilosity, apical palpomere fairly elongate. Antenna short, median antennomeres globose, c. $1.15 \mathrm{x}$ as long as wide. Two supraorbital setae present. Frons with an elongate seta at either side. Surface sparsely punctate and pilose, pilosity fairly elongate, inclined slightly anteriad, only laterally slightly denser. Microreticulation weak, in middle almost absent, surface glossy.

Prothorax (Figure 7): About as long as wide, rather quadrate, widest at apical fifth. Apical margin almost straight, apical angle very slightly produced; lateral margin very gently convex, immediately in front of the obtusely angulate basal angle slightly incurved. Base moderately narrow, considerably narrower than apex, almost straight. Apex and middle of base not margined, lateral margin comparatively wide, slightly sulcate, barely widened basad. Disk rather depressed. Median line fine, slightly impressed, ending far from apex and base. Both transverse sulci barely recognisable. Basal grooves absent. Anterior marginal seta situated at apical sixth, posterior seta located slightly in front of basal angle, both setae elongate. Surface with rather sparse, fine punctures and with fairly elongate, almost erect pilosity. Microreticulation distinct though rather superficial, consisting of large, isodiametric meshes, surface glossy.

Elytra (Figure 7): Very narrow and elongate, remarkably parallel sided, disk depressed, widest about in middle. Humerus obtusely angulate, almost rectangular, base transversal. Lateral margin behind base for a long distance absolutely straight, pilose, very finely denticulate. Apex convex. No striae perceptible. Discal sulcus shallow, wide. Surface sparsely punctate, microreticulation distinct though rather superficial, consisting of large, isodiametric meshes, surface with sparse, elongate, almost erect pilosity, rather glossy.
Disk with two discal punctures and setae at apical third and close to apex, but punctures very difficult to see within the punctation and microreticulation, because setae are broken. Marginal setae very elongate. Metathoracic wings absent.

Lower surface: Sparsely punctate and pilose, abdomen with distinct though somewhat superficial microreticulation that consists of large, isodiametric meshes. Metepisternum rather elongate, c. $1.5 \mathrm{x}$ as long as wide at apex.

Legs: Short, densely pilose. Two basal tarsomeres of male protarsus barely widened and sparsely pilose underneath.

\section{Male genitalia: Not preserved}

Female gonocoxites: Unknown.

Variation: Unknown.

\section{COLLECTING CIRCUMSTANCES}

The holotype was collected at unknown depth by scraping of a $23 \mathrm{~m}$ deep drill hole.

\section{DISTRIBUTION}

Near Pannawonica, western Pilbara, north-western Western Australia, known only from type locality.

\section{RELATIONSHIPS}

This species is most similar to G. minutus sp. nov. and G. currani sp. nov., but differs from the first by larger size, narrower pronotum, and longer elytra and from G. currani by much narrower pronotum with narrower base.

\section{ETYMOLOGY}

The name refers to the very narrow and elongate elytra of this species.

\section{Gracilanillus minutus sp. nov.}

Figure 8

urn:Isid:zoobank.org:act:1768BBD3-936F-4178-834549323954158B

\section{MATERIAL EXAMINED}

Holotype

Australia: Western Australia: ${ }^{+}$, Flinders Mine, c. $74 \mathrm{~km}$ NNW. Tom Price $22^{\circ} 07^{\prime} 02.60^{\prime \prime S} 117^{\circ} 26^{\prime} 13.70^{\prime \prime} \mathrm{E}$ (WGS 84) 13 Apr. 2011 D.C. Main, J.W. Quartermaine (HPRC0526) Trog scrape, 16 m / BINSECT0025 (WAM E84028).

\section{DIAGNOSIS}

Very small, very narrow and elongate species with rather wide pronotum and parallel-sided elytra; distinguished from similarly shaped species by 
combination of small size, relatively wide base of pronotum with comparatively obtuse basal angle, moderately elongate elytra (in genus), and rather indistinct elytral sulcus.

\section{DESCRIPTION}

Measurements: Length: $1.15 \mathrm{~mm}$; width: $0.33 \mathrm{~mm}$. Ratio width/length of pronotum: 1.11; width of base/ width of apex of pronotum: 0.96; ratio length/width of elytra: 2.04; ratio length/width of 10th antennomere: 1.1.

Colour: Upper and lower surfaces yellow, palpi, antenna, and legs pale yellow.

Head (Figure 8): Large, barely narrower than pronotum, wide, laterally convex. Eye area prominent. Upper surface gently convex. Frons with an inconspicuous, short, oblique sulcus on either side just behind the clypeal suture. Neck wide. Clypeus bisetose, setae elongate. Labrum slightly concave at apex, 6-setose. Subapical palpomere of both palpi compact and with elongate pilosity, apical palpomere elongate. Antenna short, median antennomeres globose, c. $1.1 \mathrm{x}$ as long as wide. Two supraorbital setae present. Frons with an elongate seta at either side and with a seta inside the supraorbital setae, but most setae broken. Surface sparsely but coarsely punctate and sparsely pilose, pilosity fairly elongate, inclined slightly anteriad, only laterally slightly denser. Microreticulation absent in middle, laterally indistinct, consisting of large, isodiametric meshes, surface glossy.

Prothorax (Figure 8): Perceptibly wider than long, rather quadrate, widest at apical fifth. Apical margin almost straight, apical angle very slightly produced; lateral margin very gently convex, immediately in front of the obtusely angulate basal angle shortly excised. Base wide, almost as wide as apex, very slightly convex. Apex and middle of base not margined, lateral margin narrow, barely widened basad. Disk rather depressed. Median line fine, slightly impressed, ending far from apex and base. Anterior transverse sulcus barely recognisable, posterior sulcus very shallow. Basal grooves barely perceptible. Anterior marginal puncture situated at apical fifth, posterior puncture located slightly in front of basal angle. Surface with scattered, rather coarse punctures and fairly elongate, almost erect pilosity. Microreticulation on disk absent to very superficial, laterally and near base more distinct, consisting of large, isodiametric meshes, surface glossy.

Elytra (Figure 8): Narrow and elongate, parallelsided, disk depressed, widest in middle. Humerus obtusely angulate, almost rectangular, base transverse. Lateral margin absolutely straight over much of its length, pilose, finely denticulate. Apex convex. No striae perceptible. An extremely shallow discal sulcus situated about in middle. Surface punctate, with rather sparse, elongate, almost erect pilosity. Microreiculation distinct, consisting of large, isodiametric meshes.
Discal punctures not perceptible within the coarse microreticulation, because setae are broken. Marginal setae very elongate. Metathoracic wings absent.

Lower surface: Coarsely punctate, rather sparsely pilose. Metepisternum rather elongate, c. $1.5 \mathrm{x}$ as long as wide at apex. Terminal sternum in female quadrisetose.

Legs: Short, densely pilose. Male protarsus unknown.

Male genitalia: Unknown.

Female gonocoxites: Not dissected.

Variation: Unknown.

\section{COLLECTING CIRCUMSTANCES}

The holotype was collected by scraping at an unknown depth of $<16 \mathrm{~m}$.

\section{DISTRIBUTION}

North-west of Tom Price, central Pilbara, northwestern Western Australia, known only from type locality.

\section{RELATIONSHIPS}

This species is most similar to G. bennetti sp. nov. and G. currani sp. nov., but differs from both by smaller size and shorter elytra.

\section{ETYMOLOGY}

The name refers to the very small body size of this species.

\section{Gracilanillus currani sp. nov.}

Figure 9

urn:Isid:zoobank.org:act:DDD3F746-69C1-4055-B884A0FB6C03A782

\section{MATERIAL EXAMINED}

\section{Holotype}

Australia: Western Australia: $q$, Cloudbreak, c. $87 \mathrm{~km} \mathrm{SW}$. Nullagine $22^{\circ} 20^{\prime} 26.40 " \mathrm{~S} 119^{\circ} 25^{\prime} 50.70^{\prime \prime E}$ (WGS 84) 15 Mar. 2011 M.K. Curran, J.S. Cocking (GNGC05589) Trog scrape, $15 \mathrm{~m} /$ BINSECT0023 (WAM E84026).

\section{DIAGNOSIS}

Medium sized (in genus), very narrow and elongate species with rather wide pronotum and parallel-sided elytra; distinguished from similarly shaped species by combination of relatively wide base of pronotum with denticulate basal angle, very elongate elytra (in genus), and rather indistinct elytral sulcus.

\section{DESCRIPTION}

Measurements: Length: $1.40 \mathrm{~mm}$; width: $0.37 \mathrm{~mm}$. Ratio width/length of pronotum: 1.14; width of base/ 
width of apex of pronotum: 1.0; ratio length/width of elytra: 2.13; ratio length/width of 10th antennomere: ?.

Colour: Upper and lower surfaces yellow, palpi, antenna, and legs pale yellow.

Head (Figure 9): Large, slightly narrower than pronotum, wide, laterally convex. Upper surface gently convex. Eye area less produced than in other species. Frons with an inconspicuous, short, oblique sulcus on either side just behind the clypeal suture. Neck wide. Clypeus bisetose, setae elongate. Labrum slightly concave at apex, 6-setose. Subapical palpomere of both palpi compact and with elongate pilosity, apical palpomere elongate. Both antennae broken from 2nd or 4th antennomere. Two supraorbital setae present. Frons with an elongate seta at either side and with a seta inside the supraorbital setae, but all setae broken. Surface sparsely punctate and pilose, pilosity fairly elongate, inclined slightly anteriad, only laterally slightly denser. Microreticulation distinct though slightly superficial, consisting of large, isodiametric meshes, surface glossy.

Prothorax (Figure 9): Perceptibly wider than long, rather quadrate, widest at apical fifth. Apical margin almost straight, apical angle very slightly produced; lateral margin very gently convex, immediately in front of the faintly dentiform basal angle shortly excisd. Base wide, as wide as apex, straight. Apex and middle of base not margined, lateral margin narrow, barely widened basad. Disk rather depressed. Median line fine, slightly impressed, ending far from apex and base. Anterior transverse sulcus barely recognisable, posterior sulcus shallow. Basal grooves very shallow. Anterior marginal puncture situated at apical fifth, posterior puncture located slightly in front of basal angle, but setae broken. Surface with scattered, very coarse punctures and fairly elongate, almost erect pilosity. Microreticulation distinct though rather superficial, consisting of large, isodiametric meshes, surface glossy.

Elytra (Figure 9): Very narrow and elongate, remarkably parallel-sided, disk depressed, widest in middle. Humerus obtusely angulate, slightly more obtuse than in other species, base very slightly oblique. Lateral margin absolutely straight over most of its length, pilose, finely denticulate. Apex convex. No striae perceptible. A very shallow discal sulcus situated rather close to lateral margin. Surface very coarsely punctate, microreticulation barely perceptible, surface with rather sparse, elongate, almost erect pilosity. Discal punctures not perceptible within the coarse punctation, because setae are broken. Marginal setae very elongate. Metathoracic wings absent.

Lower surface: Coarsely punctate, rather sparsely pilose. Metepisternum rather elongate, c. $1.5 \mathrm{x}$ as long as wide at apex. Terminal sternum in female quadrisetose.

Legs: Short, densely pilose. Male protarsus unknown.

Male genitalia: Unknown.

Female gonocoxites: Not dissected.

Variation: Unknown.

\section{COLLECTING CIRCUMSTANCES}

The holotype was collected by scraping at an unknown depth of $<15 \mathrm{~m}$.

\section{DISTRIBUTION}

Near Nullagine in the Pilbara, north-western Western Australia, known only from type locality.

\section{RELATIONSHIPS}

This species is most similar to G. bennetti sp. nov. and G.minutus sp. nov.; it differs from the first by wider pronotum with wider base and denticulate basal angle and by weaker elytral sulcus, and from the second by larger size and longer elytra.

\section{ETYMOLOGY}

The name is a patronym in honour of Michael Curran, one of the collectors.

\section{Gracilanillus vixsulcatus sp. nov.}

Figures 10,26

urn:Isid:zoobank.org:act:80B6A868-637C-4B37-8D7C39CD1BFEB3A0

\section{MATERIAL EXAMINED}

\section{Holotype}

Australia: Western Australia: $\uparrow$, Marillana Creek, c. $85 \mathrm{~km}$ NNW. Newman 2241'53.30"S 119²0'28.80"E (WGS 84) 13 May 2011 D.C. Main, S.R. Bennett (MA0298) Trog scrape, $18 \mathrm{~m} /$ BINSECT0024 (WAM E84027).

\section{DIAGNOSIS}

Medium sized (in genus), very narrow and elongate species with rather narrow pronotum and parallel-sided elytra; distinguished from similarly shaped species by combination of relatively narrow pronotum, very elongate elytra (in genus), and an extremely weak elytral sulcus that is only perceptible near base.

\section{DESCRIPTION}

Measurements: Length: $1.48 \mathrm{~mm}$; width: $0.38 \mathrm{~mm}$. Ratio width/length of pronotum: 0.97 ; width of base/ width of apex of pronotum: 0.98; ratio length/width of elytra: 2.15; ratio length/width of 10 th antennomere: 1.10 .

Colour: Upper and lower surfaces yellow, palpi, antenna, and legs pale yellow.

Head (Figure 10): Large, slightly narrower than pronotum, laterally convex. Eye area prominent. Upper surface gently convex. Frons with an inconspicuous, oblique sulcus on either side just behind the clypeal suture. Neck wide. Clypeus bisetose, setae elongate. 
Labrum slightly concave at apex, 6-setose. Subapical palpomere of both palpi compact and with elongate pilosity, apical palpomere fairly elongate. Antenna short, median antennomeres globose, c. $1.1 \mathrm{x}$ as long as wide. Two supraorbital setae present. Frons with an elongate seta at either side. Surface sparsely punctate and pilose, pilosity fairly elongate, inclined slightly anteriad, only laterally slightly denser. Microreticulation distinct though slightly superficial, consisting of large, isodiametric meshes, surface glossy.

Prothorax (Figure 10): Quadrate, comparatively elongate, slightly longer than wide, widest at apical third. Apical margin almost straight, apical angle very slightly produced; lateral margin apart from apical fourth very gently convex to almost straight and slightly oblique, immediately in front of the almost rectangular basal angle with a tiny, barely recognisable denticle. Base wide, about as wide as apex, almost straight. Apex and base not margined, lateral margin narrow, not widened basad. Disk depressed. Median line fine, slightly impressed, ending far from apex and base Anterior transverse sulcus not perceptible, posterior sulcus visible but faint. Basal grooves very shallow, about linear. Anterior marginal seta situated slightly in front of apical third, posterior located close to basal angle, setae elongate. Surface with rather sparse, fairly elongate, almost erect pilosity. Microreticulation rather superficial, consisting of isodiametric meshes.

Elytra (Figure 10): Very narrow and elongate, remarkably parallel sided, disk depressed, widest about in middle. Humerus almost rectangular, base transversal. Lateral margin behind base for a long distance absolutely straight, pilose, finely denticulate. Apex convex. No striae perceptible. Discal sulcus barely perceptible, only at base extremely superficial. Surface sparsely punctate, microreticulation distinct though slightly superficial, consisting of large, isodiametric meshes, surface with sparse, elongate, almost erect pilosity, rather glossy. Only one discal puncture close to apex perceptible, but puncture very difficult to see within the coarse microreticulation, because setae are broken. Marginal setae very elongate. Metathoracic wings absent.

Lower surface: Coarsely microreticulate, sparsely pilose. Metepisternum rather elongate, c. $1.5 \mathrm{x}$ as long as wide at apex. Terminal sternum in female quadrisetose.

Legs: Short, densely pilose. Male protarsus unknown.

Male genitalia: Unknown.

Female gonocoxites (Figure 26): Gonocoxite 1 compact, without setae at the apical margin. Gonocoxite 2 elongate, slightly curved, with acute apex, apparently without any ensiform setae, but with an elongate nematiform seta in upper third of the dorso-median surface that originates in a pit.

Variation: Unknown.

\section{COLLECTING CIRCUMSTANCES}

The holotype was collected by scraping at an unknown depth of $<18 \mathrm{~m}$.

\section{DISTRIBUTION}

North-west of Newman, central Pilbara, north-western Western Australia, known only from type locality.

\section{RELATIONSHIPS}

This species is very similar in body shape to the three former species, but differs from these by the barely perceptible elytral sulcus.

\section{ETYMOLOGY}

The name refers to the barely perceptible elytral sulcus.

\section{Gracilanillus cockingi sp. nov.}

Figures 11, 23

urn:Isid:zoobank.org:act:892A515C-614E-4739-BC68086248B8A26B

\section{MATERIAL EXAMINED}

\section{Holotype}

Australia: Western Australia: $\widehat{\text { Oे }}$, Solomon, c. $39 \mathrm{~km}$ W. Wittenoom $22^{\circ} 11^{\prime} 25.20^{\prime \prime S} 117^{\circ} 57^{\prime} 58.50^{\prime \prime}$ (WGS 84) 14 Sep. 2012-07 Nov. 2012 J.S. Cocking, S.R. Bennett (SM0256) Trog trap, $9 \mathrm{~m} /$ BINSECT0027 (WAM E84030).

\section{DIAGNOSIS}

Rather large (in genus), very narrow and elongate species with narrow, faintly cordiform pronotum and parallel-sided elytra; distinguished from other species by shape of pronotum that bears a slightly oblique and faintly concave lateral margin.

\section{DESCRIPTION}

Measurements: Length: $1.58 \mathrm{~mm}$; width: 0.40 $\mathrm{mm}$. Ratio width/length of pronotum: 0.98 ; width of base/width of apex of pronotum: 0.88 ; ratio width of pronotum/width of head: 1.06; ratio length/width of elytra: 2.08; ratio length/width of 10th antennomere: 1.10 .

Colour: Upper and lower surfaces yellow, palpi, antenna, and legs pale yellow.

Head (Figure 11): Large, slightly narrower than pronotum, laterally convex. Eye area prominent. Upper surface gently convex. Frons with an inconspicuous, oblique sulcus on either side just behind the clypeal suture. Neck wide. Clypeus bisetose, setae elongate. Labrum slightly concave at apex, 6-setose. Mentum with 
faint tooth. Subapical palpomere of both palpi compact and with elongate pilosity, apical palpomere moderately elongate. Antenna short, median antennomeres globose, c. $1.1 \mathrm{x}$ as long as wide. Two supraorbital setae present. Frons with an elongate seta at either side. Surface sparsely punctate and pilose, pilosity fairly elongate, inclined slightly anteriad, only laterally slightly denser. Microreticulation absent, surface very glossy.

Prothorax (Figure 11): Comparatively elongate, about as long as wide, widest at apical third, faintly cordiform. Apical margin almost straight, apical angle very slightly produced; lateral margin apart from apical fourth gently oblique, almost straight to faintly concave, immediately in front of the angulate basal angle with a tiny protuberance. Base moderately narrow, considerably narrower than apex, almost straight. Apex and base not margined, lateral margin relatively wide, slightly widened basad. Disk depressed. Median line fine, slightly impressed, ending far from apex and base. Anterior transverse sulcus barely perceptible, posterior sulcus faintly impressed. Basal grooves shallow. Anterior marginal seta situated slightly in front of apical fourth, posterior seta located close to basal angle, setae elongate. Surface with rather sparse, fairly elongate, almost erect pilosity. Microreticulation in middle superficial, laterally and in basal part more distinct, consisting of isodiametric to slightly transverse meshes.

Elytra (Figure 11): Very narrow and elongate, remarkably parallel sided, disk depressed, widest about in middle. Humerus obtusely angulate, almost rectangular, base almost transversal. Lateral margin behind base for a long distance absolutely straight, pilose, finely denticulate. Apex convex. No striae perceptible. Discal sulcus distinct and complete. Surface sparsely punctate, with sparse, elongate, almost erect pilosity. Microreticulation distinct though slightly superficial, consisting of large, isodiametric to slightly transverse meshes, surface rather glossy. Two discal punctures in apical third and close to apex perceptible, but punctures difficult to see within the coarse microreticulation, when setae are broken. Marginal setae very elongate. Metathoracic wings absent.

Lower surface: Punctate and with rather superficial microreticulation, sparsely pilose. Metepisternum rather elongate, c. $1.5 \mathrm{x}$ as long as wide at apex. Terminal sternum in male bisetose.

Legs: Short, densely pilose. Two basal tarsomeres of male protarsus barely widened and sparsely pilose underneath.

Male genitalia (Figure 23): Aedeagus short an compact, moderately wide; lower surface in basal part only moderately concave, in middle slightly convex, near apex again slightly concave. Apex short, obtusely triangular. Internal sac with one slightly sclerotised piece. Left paramere large, triangular, right paramere slenderer, both bisetose, setae on both parameres of about same length.

Female gonocoxites: Unknown.

Variation: Unknown.

\section{COLLECTING CIRCUMSTANCES}

The holotype was collected in a trap set $9 \mathrm{~m}$ below the ground surface.

\section{DISTRIBUTION}

Near Wittenoom, northern Pilbara, north-western Western Australia, known only from type locality.

\section{RELATIONSHIPS}

This species differs from all other species in the form of the pronotum, the elytral sulcus also is more distinct than in most other species.

\section{ETYMOLOGY}

The name is a patronym in honour of Jim Cocking, one of the collectors.

\section{Gracilanillus cordatus sp. nov.}

Figure 12

urn:Isid:zoobank.org:act:5BF2119E-4E36-4312-BAB595290BE2A54E

\section{MATERIAL EXAMINED}

Holotype

Australia: Western Australia: 9 , Western Hub, c. $61 \mathrm{~km}$ WNW. Tom Price $22^{\circ} 28^{\prime} 09.30^{\prime \prime} \mathrm{S}$ $117^{\circ} 15^{\prime} 22.50^{\prime \prime E}$ (WGS 84) 09 May 2013 J.W. Quartermaine, S.R. Bennett (EW0003) Trog scrape, 39 m / BINSECT0028 (WAM E84031).

\section{DIAGNOSIS}

Very small, narrow and elongate species with rather narrow, distinctly cordiform pronotum and parallelsided elytra; distinguished from other species by shape of pronotum that bears a slightly dentiform basal angle and by shorter elytra.

\section{DESCRIPTION}

Measurements: Length: $1.20 \mathrm{~mm}$; width: $0.33 \mathrm{~mm}$. Ratio width/length of pronotum: 1.02; width of base/ width of apex of pronotum: 0.79 ; ratio length/width of elytra: 1.95; ratio length/width of 10 th antennomere: 1.15 .

Colour: Upper and lower surfaces yellow, palpi, antenna, and legs pale yellow.

Head (Figure 12): Large, slightly narrower than pronotum, wide, laterally convex. Eye area moderately 
prominent. Upper surface gently convex. Frons with an inconspicuous, short, oblique and curved sulcus on either side just behind the clypeal suture. Neck wide. Clypeus bisetose, setae elongate. Labrum straight at apex, 6-setose. Subapical palpomere of both palpi compact, apical palpomere rather short. Antenna short, median antennomeres globose, c. $1.15 \mathrm{x}$ as long as wide. Two supraorbital setae present. Frons with an elongate seta at either side. Surface sparsely, rather coarsely punctate, sparsely pilose, pilosity fairly elongate, inclined slightly anteriad, only laterally pilosity slightly denser. Microreticulation absent, surface glossy.

Prothorax (Figure 12): About as long as wide, markedly cordiform, widest at apical fourth. Apical margin almost straight, apical angle very slightly produced; lateral margin regularly convex, immediately in front of the slightly dentiform basal angle with a faint concavity. Base narrow, considerably narrower than apex, convex, laterally faintly concave. Apex and middle of base not margined, lateral margin very narrow, not widened basad. Disk rather depressed. Median line fine, slightly impressed, ending far from apex and base. Anterior tranverse sulcus barely recognisable, basal transverse sulcus distinct, convex. Basal grooves very shallow. Anterior marginal seta situated slightly in front of apical third, posterior seta located close to basal angle, setae elongate. Surface with rather sparse, fairly coarse punctures and with fairly elongate, almost erect pilosity. Microreticulation barely recognisable except at apex and base, surface glossy.

Elytra (Figure 12): Narrow and elongate but shorter than in all other species of the genus, parallel-sided, disk depressed, widest at basal fourth. Humerus obtusely angulate, almost rectangular, base transversal. Lateral margin behind basal third straight, pilose, finely denticulate in basal half. Apex convex. No striae perceptible. Discal sulcus distinct, wide. Surface sparsely punctate, microreticulation distinct though rather superficial, almost isodiametric, with sparse, elongate, almost erect pilosity; surface rather glossy. Disk with two discal punctures and setae at apical third and close to apex, but punctures very difficult to see within the punctation and microreticulation, because setae are broken. Marginal setae very elongate. Metathoracic wings absent.

Lower surface: Sparsely but coarsely punctuate and pilose, abdomen without microreticulation. Metepisternum rather elongate, c. $1.5 \mathrm{x}$ as long as wide at apex. Terminal sternum in female quadrisetose.

Legs: Short, densely pilose. Male protarsus unknown.

Male genitalia: Unknown.

Female gonocoxites: Not dissected.

Variation: Unknown.

\section{COLLECTING CIRCUMSTANCES}

The holotype was collected at unknown depth by scraping a $39 \mathrm{~m}$ deep drill hole.

\section{DISTRIBUTION}

Near Tom Price, central Pilbara, north-western Western Australia, known only from type locality.

\section{RELATIONSHIPS}

This species differs from all other species of the genus in the shape of pronotum and length of elytra. In view of the almost rectangular humerus, shape and length of elytra, and chetotaxy of head and elytra, it is included in the genus Gracilanillus. This species is not as closely related to other species of the genus.

\section{ETYMOLOGY}

The name refers to the rather cordiform shape of the pronotum.

\section{Genus Hesperanillus gen. nov.}

urn:Isid:zoobank.org:act:182372E0-0CE8-4A7F-A784A361A9B72661

\section{TYPE SPECIES}

Hesperanillus scanloni sp. nov., by present designation.

\section{DIAGNOSIS}

Medium sized, depigmented, yellow to pale red species. Surface of head and pronotum with inconspicuous, isodiametric to slightly transverse microreticulation, elytra with coarse punctation and/or microreticulation, surface rather sparsely pubescent.

Head large, barely narrower than pronotum. Eye absent, head laterally convex; eye area remarkably prominent. Mandibles short. Maxillary palpus short, preapical palpomere globose, with sparse but elongate pilosity; labial palpus small; apical palpomeres of both palpi remarkably elongate. Labium transverse. Mentum not fused to submentum, mental tooth present though faint. Two supraorbital seta and one clypeal seta present, also one seta on frons. Antenna short, rather globose.

Pronotum wide, cordiform, with narrow basis as compared with apex. Apical angle barely produced, basal angle angulate or even denticulate. Margin bisetose.

Elytra rather differently shaped, but not absolutely parallel-sided, more or less oval-shaped, narrowed basad. Humerus obliquely convex, base transversal to slightly oblique. Lateral margin rather straight to convex, apex rounded, not emarginate nor transverse. Surface depressed, striae absent, without discal sulcus. Lateral margin coarsely denticulate, at least in basal half, and pilose; scutellary puncture present but difficult to detect within the coarse punctation; one or two discal punctures present but barely discernible. Microreticulation various, isodiametric to slightly 
transverse. Punctation various. Surface rather sparsely pilose.

Metathoracic wings absent.

Legs short, profemur not dentate. 1st and 2nd tarsomeres of male protarsus slightly dilated and pilose.

Lower surface microreticulate and sparsely pilose.

Aedeagus rather compact, lower surface in basal part markedly curved, in apical three fourths straight, apex moderately short, slightly produced, narrow, with obtusely triangular tip. Internal sac with one slightly sclerotised piece. Parameres fairly differently shaped, right paramere slenderer than left, both with two elongate apical setae.

Gonocoxite 2 rather elongate, slightly curved, with acute apex, without ensiform setae, with an elongate subapical nematiform seta.

\section{DISTRIBUTION}

Three species recorded from the Pilbara, northwestern Western Australia. Collected at depths up to 58 $\mathrm{m}$ below ground surface. Nothing is known about habits, diet, and reproduction.

\section{RELATIONSHIPS}

In the absence of the elytral sulcus the genus is similar to the eastern genera Austranillus, Tasmanillus, and Pseuillaphanus, but it is distinguished from all of these by the markedly produced eye area and the elongate and/or differently shaped elytra. In certain characters of body shape, except for shape of head and the strong denticulation of the lateral margins of the elytra, it matches the similarly Western Australian Externanillus, which is probably the most closely related genus.

\section{ETYMOLOGY}

The name refers to the occurrence of all species in Western Australia: lat. hortus Hesperidae is the garden in the far west.

\section{Hesperanillus scanloni sp. nov.}

Figures 13, 24

urn:Isid:zoobank.org:act:D4D0853D-1AB3-45A2-BAB5013B1F4C9364

\section{MATERIAL EXAMINED}

\section{Holotype}

Australia: Western Australia: Ô, Phil's Creek, c. $100 \mathrm{~km}$ NNW. Newman $22^{\circ} 44^{\prime} 04.7^{\prime S} 119^{\circ} 11^{\prime} 06.8^{\prime \prime E}$ (WGS 84) 10 Mar. 2009 M.D.Scanlon, G.B. Pearson (PROP009) Troglofauna scrape, $20 \mathrm{~m}$ (WAM E84115).

\section{DIAGNOSIS}

Moderately large, narrow and elongate, depressed, flavous species with remarkably cordiform pronotum and narrow, almost parallel-sided elytra; distinguished from other species by shape of pronotum, and longer elytra with oblique-convex humerus.

\section{DESCRIPTION}

Measurements: Length: $1.78 \mathrm{~mm}$; width: $0.54 \mathrm{~mm}$. Ratio width/length of pronotum: 1.18; width of base/ width of apex of pronotum: 0.77 ; ratio length/width of elytra: 1.84; ratio length/width of 10 th antennomere: 1.25 .

Colour: Upper and lower surfaces pale red, palpi, antenna, and legs yellow.

Head (Figure 13): Large, barely narrower than pronotum, laterally convex. Eye area markedly prominent. Upper surface gently convex. Frons with a conspicuous, elongate, oblique and curved sulcus on either side from just behind the clypeal suture. Neck wide. Clypeus bisetose, setae elongate. Labrum slightly concave at apex, 6-setose. Subapical palpomere of both palpi large, with some elongate setae, apical palpomere remarkably elongate. Antenna short, median antennomeres globose, c. $1.25 \mathrm{x}$ as long as wide. Frons with an elongate seta at either side. Two elongate supraorbital setae present. Surface sparsely pilose, pilosity elongate and slightly inclined anteriad, laterally pilosity slightly denser. Surface sparsely punctuate, Microreticulation rather superficial, about isodiametric to slightly transverse.

Prothorax (Figure 13): Wide, decidedly cordiform, much wider than long, widest at apical third. Apical margin straight, apical angle barely produced; lateral margin convex, in basal sixth concave, basal part of margin straight, immediately in front of the rectangular, faintly denticulate basal angle with a faint, obtuse protuberance. Base narrow, considerably narrower than apex, very slightly bisinuate. Apex and middle of base not margined, lateral margin narrow, not widened basad. Disk rather depressed. Median line fine, slightly impressed, ending far from apex and base. Apical transverse sulcus faint, basal transverse sulcus moderately impressed. Basal grooves shallow, about cicular. Anterior marginal seta situated about at apical third, posterior seta located close to basal angle, setae elongate. Surface sparsely punctuate and pilose, pilosity fairly elongate, almost erect. Microreticulation absent except near apex and base, surface glossy.

Elytra (Figure 13): Narrow and elongate, not exactly parallel-sided, disk gently convex, widest about in middle. Humerus rounded, base slightly oblique. Lateral margin behind basal third almost straight, pilose, completely, rather coarsely denticulate. Apex convex. No striae perceptible. Discal sulcus absent. Surface 
coarsely punctate, microreticulation distinct though slightly superficial, isodiametric to slightly transverse; surface with moderately sparse, fairly elongate, almost erect pilosity. Disk with two discal punctures and setae at apical third and close to apex, but punctures very difficult to detect within the coarse punctation, because all setae are broken. Marginal setae when visible, very elongate. Metathoracic wings absent.

Lower surface: Rather coarsely microreticulate, sparsely pilose. Metepisternum rather short, c. $1.25 \mathrm{x}$ longer than wide. Terminal sternum in male bisetose.

Legs: Short, densely pilose. In male two basal tarsomeres of protarsus barely widened and sparsely pilose underneath.

Male genitalia (Figure 24): Aedeagus compact, moderately wide; lower surface in basal part deeply concave, in apical four fifth straight. Apex moderately elongate, obtusely triangular. Internal sac with one sinuate, moderately sclerotised piece. Left paramere large, triangular, right paramere slenderer, both bisetose, setae on both parameres of about same length.

Female gonocoxites: Unknown.

Variation: Unknown.

\section{COLLECTING CIRCUMSTANCES}

The holotype was collected at unknown depth by scraping a $20 \mathrm{~m}$ deep drill hole.

\section{DISTRIBUTION}

North-west of Newman, central Pilbara, north-western Western Australia, known only from type locality.

\section{RELATIONSHIPS}

In shape of elytra this species is most similar to H. laticollis sp. nov. but its relationships are uncertain.

\section{ETYMOLOGY}

The name is a patronym in honour of Mike Scanlon, one of the collectors.

\section{Hesperanillus laticollis sp. nov.}

Figure 14

urn:Isid:zoobank.org:act:FF6ED86B-BFA7-45CC-A2A14D9370E47C15

\section{MATERIAL EXAMINED}

\section{Holotype}

Australia: Western Australia: ${ }^{2}$, Flinders Mine, c. $66 \mathrm{~km}$ NNW. Tom Price $22^{\circ} 10^{\prime} 37.80^{\prime \prime S} 117^{\circ} 28^{\prime} 23.90^{\prime \prime} \mathrm{E}$ (WGS 84) 27 Jul. 2011 J.S. Cocking, J.W. Quartermaine (HPRC4214) Trog scrape, 58 m / BINSECT0026 (WAM E84029).

\section{DIAGNOSIS}

Rather small, narrow and fairly elongate, depressed, flavous species with wide, gently cordiform pronotum and narrow, almost parallel-sided elytra; distinguished from other species by shape of pronotum, and moderately narrow and elongate elytra with almost rectangular humerus.

\section{DESCRIPTION}

Measurements: Length: c. $1.50 \mathrm{~mm}$; width: $0.40 \mathrm{~mm}$. Ratio width/length of pronotum: c. 1.32; width of base/ width of apex of pronotum: c. 0.78 ; ratio length/width of elytra: 1.75; ratio length/width of 10th antennomere: 1.15 .

Colour: Upper and lower surfaces pale red, palpi, antenna, and legs yellow.

Head (Figure 14): Large, slightly narrower than pronotum, wide, laterally convex. Eye area markedly prominent. Upper surface gently convex. Frons with a short, straight sulcus on either side just behind the clypeal suture. Neck wide. Clypeus bisetose, setae elongate. Labrum slightly concave at apex, 6-setose. Mentum with short, obtuse tooth. Subapical palpomere of both palpi compact and with elongate pilosity, apical palpomere elongate. Antenna short, median antennomeres globose, c. $1.15 \mathrm{x}$ as long as wide. Two supraorbital setae present. Frons with an elongate seta at either side, and with an additional seta inside of the supraorbital setae. Surface sparsely punctate and pilose, pilosity fairly elongate, inclined slightly anteriad, only laterally slightly denser. Microreticulation rather superficial, in middle more than laterally, consisting of large, isodiametric to slightly transverse meshes, surface glossy.

Prothorax (Figure 14): Rather damaged, broken in middle, therefore measurements only approximated. Considerably wider than long, somewhat cordiform, widest at apical fourth. Apical margin slightly concave, apical angle slightly produced; lateral margin convex, immediately in front of the angulate basal angle straight. Base rather narrow, considerably narrower than apex, slightly convex. Apex and middle of base not margined, lateral margin comparatively wide, barely widened basad. Disk rather depressed. Median line not visible, because pronotum broken in middle. Both transverse sulci faint, the anterior one barely impressed, the posterior sulcus slightly deeper. Basal grooves shallow, about circular. Anterior marginal seta situated slightly in front of apical fourth, posterior seta located near basal angle, both setae elongate. Surface with rather sparse, coarse punctures and with fairly elongate, almost erect pilosity. Microreticulation distinct though in middle very weak, consisting of large, isodiametric to slightly transverse meshes, surface glossy. 
Elytra (Figure 14): Rather narrow and elongate, almost parallel sided, disk comparatively convex, widest about in middle. Humerus obtusely angulate, base transversal. Lateral margin very slightly convex, pilose, margin in basal half rather coarsely denticulate. Apex convex. No striae perceptible. Discal sulcus absent. Surface sparsely punctate, microreticulation distinct, consisting of very large, isodiametric meshes, surface with sparse, elongate, almost erect pilosity, rather glossy. Discal punctures not perceptible within the coarse microreticulation, because setae are broken. Marginal setae very elongate. Metathoracic wings absent.

Lower surface: Sparsely punctate and pilose, abdomen with distinct though slightly superficial microreticulation that consists of large, isodiametric meshes. Metepisternum rather short, c. $1.25 \mathrm{x}$ longer than wide at apex. Terminal sternum in female quadrisetose.

Legs: Short, densely pilose. Male protarsus unknown.

Male genitalia: Unknown.

Female gonocoxites: Not dissected.

Variation: Unknown.

\section{COLLECTING CIRCUMSTANCES}

The holotype was collected by scraping at an unknown depth from a drill hole $58 \mathrm{~m}$ deep.

\section{DISTRIBUTION}

Near Tom Price, central Pilbara, north-western Western Australia, known only from type locality.

\section{RELATIONSHIPS}

In shape of elytra this species is most similar to H. scanloni sp. nov. but the relationships are uncertain.

\section{ETYMOLOGY}

The name refers to the wide pronotum.

\section{Hesperanillus bicostatus sp. nov.}

Figures 15, 27

urn:Isid:zoobank.org:act:A0CDDA4B-0B8A-438A-90618D655E03211C

\section{MATERIAL EXAMINED}

\section{Holotype}

Australia: Western Australia: $q$, Mining Area C, c. $95 \mathrm{~km}$ WNW. Newman $22^{\circ} 55^{\prime} 49.80^{\prime \prime S} 118^{\circ} 56^{\prime} 33.90^{\prime \prime E}$ (WGS 84) 12 Jan. 2008-13 Mar. 2008 J.S. Cocking, M.D. Scanlon (GD0031R) Trog trap / BINSECT0018 (WAM E84013).

\section{DIAGNOSIS}

Moderately large, rather wide, depressed, pale red species with cordiform pronotum and wide, reversely oviform elytra; distinguished from other species by shape of pronotum and elytra, and the presence of elytral ridges.

\section{DESCRIPTION}

Measurements: Length: $1.76 \mathrm{~mm}$; width: $0.60 \mathrm{~mm}$. Ratio width/length of pronotum: 1.20; width of base/ width of apex of pronotum: 0.88 ; ratio length/width of elytra: 1.65; ratio length/width of 10 th antennomere: 1.15 .

Colour: Upper and lower surfaces pale red, palpi, antenna, and legs yellow.

Head (Figure 15): Large, barely narrower than pronotum, wide, laterally convex. Eye area markedly prominent. Upper surface gently convex. Frons with a conspicuous, fairly elongate, oblique and curved sulcus on either side just behind the clypeal suture. Neck wide. Clypeus bisetose, setae elongate. Labrum slightly concave at apex, 6-setose. Subapical palpomere of both palpi compact and with elongate pilosity, apical palpomere moderately elongate. Antenna short, median antennomeres globose, c. $1.15 \mathrm{x}$ as long as wide. Two supraorbital setae present. Frons with an elongate seta at either side. Surface sparsely punctate and pilose, pilosity fairly elongate, inclined slightly anteriad, only laterally slightly denser. Microreticulation weak, in middle almost absent, surface glossy.

Prothorax (Figure 15): Much wider than long, markedly cordiform, widest at apical forth. Apical margin almost straight, apical angle very slightly produced; lateral margin near apex convex, then almost straight to faintly concave, in front of the dentiform basal angle with slight incision. Base rather narrow, considerably narrower than apex, in middle produced, near basal angle excised. Apex and middle of base not margined, lateral margin comparatively wide, barely widened basad. Disk rather depressed. Median line fine, slightly impressed, ending far from apex and base. Anterior transverse sulcus barely recognisable, posterior sulcus oblique, deep, interrupted in middle. Basal grooves rather deep, about linear. Anterior marginal seta situated at apical fifth, posterior seta located slightly in front of basal angle, both setae elongate. Surface with sparse, fine punctures and with sparse, fairly elongate, almost erect pilosity. Microreticulation only distinct near base, consisting of large, isodiametric meshes, surface glossy.

Elytra (Figure 15): Wide and reversely ovoid, widest about in middle, disk moderately depressed. Humerus rounded, base almost transversal. Lateral margin almost completely convex, pilose, in basal half coarsely denticulate. Apex convex, very slightly incurved. No striae perceptible. Disk in middle with a straight, shallow ridge, inside of the ridges disk 
depressed. No distinct discal sulcus present. Surface with sparse, elongate, almost erect pilosity, punctation very fine, barely perceptible. Microreticulation distinct, consisting of large, isodiametric meshes. One discal puncture near apex hardly perceptible within the strong microreticulation, because setae are broken. Marginal setae very elongate. Metathoracic wings absent.

Lower surface: Sparsely but rather coarsely punctate, sparsely pilose, abdomen with perceptible but rather superficial microreticulation only laterally and at base. Metepisternum fairly short, c. $1.25 \mathrm{x}$ as long as wide at apex. Terminal sternum in female apparently quadrisetose.

Legs: Relatively elongate, densely pilose. Male protarsus unknown.

Male genitalia: Unknown.

Female gonocoxites (Figure 27): Gonocoxite 1 compact, without setae at the apical margin. Gonocoxite 2 moderately elongate, slightly curved, with acute apex, apparently without any ensiform setae, but with an elongate nematiform seta in upper third of the dorso-median surface that originates in a pit.

Variation: Unknown.

\section{COLLECTING CIRCUMSTANCES}

The holotype was collected in a troglofauna trap set at unknown depth in a $66 \mathrm{~m}$ deep drill hole.

\section{DISTRIBUTION}

North-west of Newman, central Pilbara, north-western Western Australia, known only from type locality.

\section{RELATIONSHIPS}

This species differs in some character states from the other, rather similarly shaped species of the genus, namely in the shorter, ovoid elytra, and the presence of longitudinal elytral ridges.

\section{ETYMOLOGY}

The name refers to the presence of a longitudinal ridge on either elytron.

\section{Hesperanillus sp. indet.}

\section{MATERIAL EXAMINED}

\section{Holotype}

Australia: Western Australia: + (?), East Pit, c. $45 \mathrm{~km}$ S. Pannawonica $22^{\circ} 00^{\prime} 25.2^{\prime \prime S} 116^{\circ} 31^{\prime} 24.0^{\prime \prime E}$ (WGS 84) 22 Jul. 2012 G.B. Pearson, S.R. Bennett (BH138) Scrape $13 \mathrm{~m} / \mathrm{BENN051}$ (WAM E84040).

\section{NOTES}

Because the single specimen is rather damaged (without head, only parts of the prothorax are preserved), it is not formally described, although it seems to represent another new species, according to shape and structure of elytra and pronotum.

The sample also contains a larva that likely could belong to this species. However, I prefer not to describe the larva, until both specimens have been barcoded to confirm or deny whether they are conspecific.

\section{DIAGNOSIS}

Small, narrow and elongate, depressed, flavous species with slightly cordiform pronotum and narrow and elongate, almost parallel-sided elytra; distinguished from other species by less cordiform pronotum with probably wider base and by longer elytra.

\section{DESCRIPTION}

Measurements (head lost, prothorax damaged): Length: c. $1.35 \mathrm{~mm}$; width: $0.40 \mathrm{~mm}$. Ratio width/ length of pronotum: ?; width of base/width of apex of pronotum: ?; ratio length/width of elytra: 2.02; ratio length/width of 10th antennomere: ?.

Colour: Upper and lower surfaces pale red, palpi, antenna, and legs yellow.

\section{Head: Lost.}

Prothorax: Very much damaged, only part of the left half preserved. Slightly cordiform, widest at apical fourth. Lateral margin gently convex, immediately in front of the angulate basal angle slightly concave. Base moderately wide, probably slightly narrower than apex, rather convex.

Elytra: Narrow and elongate, almost parallel sided, disk comparatively convex, widest about in middle. Humerus rounded, base slightly oblique. Lateral margin in middle almost straight, pilose, margin in anterior two thirds rather coarsely denticulate. Apex convex. No striae perceptible. Discal sulcus absent. Surface sparsely punctate, microreticulation distinct, consisting of very large, isodiametric meshes, surface with sparse, elongate, almost erect pilosity, rather glossy. No discal punctures perceptible within the coarse microreticulation, because setae are broken. Marginal setae, when present, very elongate. Metathoracic wings absent.

Lower surface: Sparsely punctate and pilose, abdomen with distinct though somewhat superficial microreticulation that consists of large, isodiametric meshes. Metepisternum moderately elongate, c. $1.3 \mathrm{x}$ as long as wide at apex. Setosity of terminal sternum not perceptible.

Legs: Short, densely pilose. Male protarsus unknown.

Male genitalia: Unknown.

Female gonocoxites: Unknown.

Variation: Unknown.

\section{COLLECTING CIRCUMSTANCES}

The specimen was collected by scraping from an unknown depth of $<17 \mathrm{~m}$. 


\section{DISTRIBUTION}

Near Pannawonica, western Pilbara, north-western Western Australia, known only from a single locality.

\section{RELATIONSHIPS}

This species is tentatively included in the genus Hesperanillus, mainly because of absence of the elytral sulcus and of the gently cordiform pronotum. However, its relationships remain unresolved until additional, complete specimens are available.

\section{Genus Externanillus gen. nov.}

\author{
urn:Isid:zoobank.org:act:6B26CBFA-F1C2-4B94-9473- \\ A9B5EE883663
}

\section{TYPE SPECIES}

Externanillus mcraeae sp. nov., by monotypy.

\section{DIAGNOSIS}

Body size small. Colour depigmented, yellow. Surface with inconspicuous, isodiametric to slightly transverse microreticulation, elytra with coarse microreticulation, surface rather sparsely pubescent.

Head moderately large, considerably narrower than pronotum. Eye absent, head laterally convex, but eye area not prominent. Mandibles short. Maxillary palpus short, preapical palpomere globose, with sparse but elongate pilosity; labial palpus small; apical palpomere of labial palpus elongate. Labium transverse. Mentum not fused to submentum, mental tooth present though faint. Two supraorbital seta and one clypeal seta present, also one seta on frons. Antenna short, globose.

Pronotum rather narrow, gently cordiform, lateral margin evenly convex; base narrow as compared with apex. Apical angle barely produced, basal angle oblique but with an extremely faint denticle. Margin bisetose.

Elytra elongate, gently oval-shaped, narrowed basad. Humerus widely rounded, base slightly oblique. Lateral margin gently but evenly convex, apex rounded, not emarginate nor transverse. Surface depressed, striae absent, without discal sulcus. Lateral margin only finely denticulate, pilose; scutellary puncture present but difficult to detect within the coarse microreticulation; one discal puncture present but barely discernible. Microreticulation distinct and coarse, isodiametric to slightly transverse. Punctation fine. Surface rather sparsely pilose.

Metathoracic wings absent.

Legs short, profemur not dentate. Male protarsus unknown.

Lower surface microreticulate and sparsely pilose.

Aedeagus unknown.

Gonocoxite 2 elongate, markedly curved, acute, without ensiform setae, with an extremely elongate subapical nematiform seta.

\section{DISTRIBUTION}

The single species occurs in the Yilgarn region, inland southern Western Australia. The holotype was sampled in a troglofauna trap set at $50 \mathrm{~m}$. Nothing is known about habits, diet, and reproduction.

\section{RELATIONSHIPS}

Externanillus is similar to the eastern genera Austranillus, Tasmanillus, and Pseudillaphanus in the absence of the elytral sulcus, but it is distinguished from all of these genera by the elongate and/or differently shaped elytra and narrower pronotum. In certain characters of body shape, except for shape of head, it matches the similarly Western Australian genus Hesperanillus, to which it is likely to be most closely related.

\section{ETYMOLOGY}

The name refers to the occurrence of this species outside the Pilbara.

\section{Externanillus mcraeae sp. nov.}

Figures 16, 28

urn:Isid:zoobank.org:act:7473FCCC-9ACC-4975-9D307D44C177BEB3

\section{MATERIAL EXAMINED}

\section{Holotype}

Australia: Western Australia: $\hat{\jmath}$, Carina Extension, c. $62 \mathrm{~km} \mathrm{NE}$. Koolyanobbing $30^{\circ} 26^{\prime} 07.50^{\prime \prime S}$ 11958'41.50"E (WGS 84) 04 Aug. 2010 . 21 Sep. 2010 J.M. McRae, J.S. Cocking (CXRC0017) Trog trap, 50 m / BINSECT0030 (WAM E84037).

\section{DIAGNOSIS}

Small, rather narrow, depressed, flavous species with slightly cordiform pronotum and narrow, slightly ovalshaped elytra with rounded humerus.

\section{DESCRIPTION}

Measurements (specimen slightly damaged): Length: $1.35 \mathrm{~mm}$; width: $0.42 \mathrm{~mm}$. Ratio width/length of pronotum: 1.05; width of base/width of apex of pronotum: 0.85 ; ratio length/width of elytra: 1.82; ratio length/width of 10th antennomere: 1.1.

Colour: Upper and lower surfaces, and palpi, antenna, and legs pale yellow.

Head (Figure 16): Moderately large, perceptible narrower than pronotum, laterally convex. Eye are little produced laterad. Upper surface gently convex. Frons with a short, straight sulcus on either side just behind the clypeal suture. Neck wide. Clypeus bisetose, setae elongate. Labrum slightly concave at apex, 6-setose. Mentum with short, obtuse tooth. Subapical palpomere of both palpi compact and with elongate pilosity, apical 
palpomere of labial palpus elongate, of maxillary palpi broken. Antenna short, median antennomeres globose, c. $1.1 \mathrm{x}$ as long as wide. Two supraorbital setae present. Frons with an elongate seta at either side. Surface sparsely punctate and pilose, pilosity fairly elongate, inclined slightly anteriad, only laterally slightly denser. Microreticulation superficial, in middle more than laterally, consisting of large, isodiametric to slightly transverse meshes, surface glossy.

Prothorax (Figure 16): Little wider than long, cordiform, widest slightly in front of apical third. Apical margin almost straight, apical angle barely produced; lateral margin convex, immediately in front of the faintly dentiform basal angle very shortly excised. Base rather narrow, considerably narrower than apex, in middle almost straight, laterally oblique. Apex and middle of base not margined, lateral margin comparatively wide, barely widened basad. Disk rather depressed. Median line distinct, elongate. Both transverse sulci faint, the anterior one barely impressed, the posterior one slightly deeper. Basal grooves shallow, about circular. Anterior marginal seta situated slightly in front of apical third, posterior seta located near basal angle, both setae elongate. Surface with rather sparse, coarse punctures and with fairly elongate, almost erect pilosity. Microreticulation only near base distinct, consisting of large, isodiametric to slightly transverse meshes, surface glossy.

Elytra (Figure 16): Rather narrow and elongate, not parallel sided but gently ovoid, disk rather depressed, widest about in middle. Humerus widely rounded, base slightly oblique. Lateral margin gently convex throughout, pilose, margin in basal half faintly denticulate. Apex convex. No striae perceptible. Discal sulcus absent. Punctation of surface not perceptible within the distinct microreticulation that consists of very large, isodiametric meshes; surface with sparse, elongate, almost erect pilosity, rather glossy. One discal puncture present at apical fourth, but punctures barely perceptible within the coarse microreticulation, when setae are broken. Marginal setae, when present, very elongate. Metathoracic wings absent.

Lower surface: Sparsely punctate and pilose, abdomen with rather superficial microreticulation that consists of large, isodiametric meshes. Metepisternum rather short, c. $1.25 \mathrm{x}$ as long as wide at apex. Terminal sternum in female quadrisetose.

Legs: Short, densely pilose. Male protarsus unknown.

Male genitalia: Unknown.

Female gonocoxites (Figure 28): Gonocoxite 1 compact, without setae at the apical margin. Gonocoxite 2 rather compact, very curved, with acute apex, apparently without any ensiform setae, but with a remarkably stout and very elongate nematiform seta in upper third of the dorso-median surface that originates in a pit.

Variation: Unknown.

\section{COLLECTING CIRCUMSTANCES}

The holotype was collected in a troglofauna trap set at $50 \mathrm{~m}$.

\section{DISTRIBUTION}

Near Koolyanobbing, inland southern Western Australia, known only from type locality.

\section{ETYMOLOGY}

The name is a patronym in honour of Jane McRae, one of the collectors.

\section{Genus Angustanillus gen. nov.}

urn:Isid:zoobank.org:act:ECED5CE7-CE6B-4A6B-972C7BF7EB48BEF6

\section{TYPE SPECIES}

Angustanillus striatipennis sp. nov., by monotypy.

\section{DIAGNOSIS}

Body size large (in group). Colour depigmented, pale red. Surface with very coarse, isodiametric to slightly transverse microreticulation, pronotum also with sparse but very coarse punctation, surface rather sparsely pubescent.

Head large, slightly narrower than pronotum. Eye wanting, head laterally convex. Mandibles short. Maxillary palpus short, preapical palpomere globose, densely pilose, apical palpomere tiny, barely recognisable. Labial palpus small, labium transverse. Mentum not fused to submentum, mental tooth absent. One supraorbital seta and one clypeal seta present, also one seta on frons and another inside the position of the not visible posterior supraorbital seta. Antenna very short, globose.

Pronotum narrow and elongate, almost parallel-sided, with rather wide basis. Apical angle slightly produced, basal angle angulate. Lateral margin faintly denticulate just in front of the basal angle. Margin probably bisetose.

Elytra extremely narrow and elongate, absolutely parallel-sided. Humerus almost rectangular. Lateral margin straight, apex oblique, not emarginate. Surface in middle depressed, laterally sloping down; four internal striae well visible, without discal sulcus. Lateral margin finely serrulate and pilose; scutellary puncture present but difficult to detect within the coarse microstructure; 2 discal punctures present but barely discernible. Microreticulation very coarse, almost isodiametric. Surface rather sparsely pilose.

Metathoracic wings absent.

Legs short, profemur not dentate.

Lower surface coarsely microreticulate and sparsely pilose.

Aedeagus unknown.

Gonocoxites unknown. 


\section{DISTRIBUTION}

A single species recorded from the western Pilbara, north-western Western Australia. Sampled by 'Troglofauna trap scrape' without indication of depth. Nothing else is known about habits, diet, and reproduction.

\section{RELATIONSHIPS}

This genus differs in important character states from all other species described in the present paper: namely extremely narrow and elongate body shape, presence of four distinct elytral striae, very coarse microreticulation of the whole surface, and coarse punctation of the pronotum.

\section{ETYMOLOGY}

The name refers to the very narrow and elongate body shape.

\section{Angustanillus striatipennis sp. nov.}

Figure 17

urn:Isid:zoobank.org:act:E55927FC-6CE4-4AAB-8FA689A226DD03B5

\section{MATERIAL EXAMINED}

\section{Holotype}

Australia: Western Australia: 9 , Mesa A, $60 \mathrm{~km} \mathrm{~W}$ of Pannawonica 2140'37.099"S 115¹5'53.794"E (GPS WGS 84) 20 October 2013, P. Brooshooft, M. Greenham Biota: MEARC5070-01, n=1 Troglofauna trap scrape (WAM E88545).

\section{DIAGNOSIS}

Large, extremely narrow and elongate, depressed, pale rufous species with rather quadrate pronotum and absolutely parallel-sided elytra; elytral sulcus absent, but four striae present and distinct.

\section{DESCRIPTION}

Measurements: Length: $2.4 \mathrm{~mm}$; width: $0.55 \mathrm{~mm}$. Ratio width/length of pronotum: 0.86 ; width of base/ width of apex of pronotum: 0.89; ratio length/width of elytra: 2.23; ratio length/width of 10th antennomere: 1.0 .

Colour: Upper and lower surfaces pale red, palpi, antenna, and legs yellow.

Head (Figure 17): Very slightly narrower than pronotum, comparatively wide, laterally convex. Upper surface gently convex. Frons with an inconspicuous, oblique and curved sulcus on either side just behind the clypeal suture. Neck wide. Clypeus bisetose, setae elongate. Labrum straight at apex, probably 6-setose but only the lateral seta preserved. Subapical palpomere of maxillary palpus relatively narrow, apical palpomere tiny, barely perceptible. Antenna very short, median antennomeres globose, c. as wide as long. Frons with an elongate seta at either side, the anterior supraorbital seta present, the posterior one apparently absent, but with a seta inside of position of eye far back and removed to middle. Surface very sparsely pilose, pilosity short and inclined slightly anteriad, only laterally pilosity slightly denser. Microreticulation distinct and very coarse, about isodiametric.

Prothorax (Figure 17): Elongate, distinctly longer than wide, almost parallel-sided, widest at apical third. Apical margin slightly concave, apical angle slightly produced; lateral margin apart from apical fourth very gently convex to almost straight and slightly oblique, immediately in front of the almost rectangular, extremely faintly denticulate basal angle with a short, obtuse protuberance. Base wide, slightly narrower than apex, slightly convex. Apex and base not margined, lateral margin very faintly serrulate; lateral marginal sulcus extremely narrow, not widened basad. Disk rather depressed. Median line fine, slightly impressed, ending far from apex and base. Anterior transverse sulcus absent, posterior sulcus visible but faint. Basal grooves barely indicated. Anterior marginal seta situated about at apical fourth, seta elongate; posterior marginal seta not preserved. Surface with sparse, fairly elongate, almost erect pilosity. Microreticulation distinct and coarse, almost isodiametric, surface with sparse, large and deep punctures.

Elytra (Figure 17): Extremely narrow and elongate, exactly parallel-sided, only near middle very faintly concave; disk in middle gently convex, laterally with an obtuse ridge so that the lateral fourth is sloping down. Humerus almost rectangular, base very slightly oblique. Lateral margin finely denticulate, sparsely pilose. Apex oblique-convex. Four median striae well perceptible, with large but shallow, inconspicuous punctures. Virtually no discal sulcus perceptible. Surface with very coarse, about isodiametric microreticulation, with comparatively sparse, almost erect pilosity. Scutelly puncture not perceptible, because setae broken. Disk with two discal punctures at basal fifth and apical fourth, but, as setae not preserved, punctures barely perceptible within the coarse microreticulation and the punctation. Marginal setae very elongate. Metathoracic wings absent.

Lower surface: Coarsely microreticulate, sparsely pilose. Metepisternum elongate, $>1.5 \mathrm{x}$ as long as wide at apex. Setosity of terminal sternum not perceptible.

Legs: Rather short, densely pilose. Anterior leg lacking on both sides.

Male genitalia. Unknown.

Female gonocoxites: Not dissected, apparently partly destroyed.

Variation: Unknown.

\section{COLLECTING CIRCUMSTANCES}

The holotype was sampled by 'Troglofauna trap scrape' but without indication of depth, as noted under 'Collecting method'. 


\section{DISTRIBUTION}

Near Pannawonica, western Pilbara, north-western Western Australia, known only from type locality.

\section{ETYMOLOGY}

The name refers to the presence of several distinct elytral striae.

\section{KEY TO THE SPECIES OF MACRANILLUS GEN NOV.}

1. Body size larger, length $>2.8 \mathrm{~mm}$; aedeagus see Figure 20 M. magnus sp. nov.

Body size smaller, length $<2.5 \mathrm{~mm}$...... 2

2. Lateral margin of pronotum in basal half perceptibly concave, base narrower, ratio base/apex $<1.07$ (Figure 5); aedeagus see Figure 21

M. quartermaini sp. nov.

Lateral margin of pronotum in basal half convex, base wider, ratio base/apex $>1.10$ (Figures 1-3)

3

3. Base of pronotum relatively narrow as compared with apex, ratio base/apex $<1.14$; either elytra longer, ratio length/width $>1.80$, or shorter, ratio $1 / \mathrm{w}<1.70$ (Figures $2-3$ )

\section{4}

Base of pronotum relatively wide as compared with apex, ratio base/apex $>1.19$; elytra medium sized, ratio length/width 1.73-1.77 (Figure 1); aedeagus see Figure 18 M. bennetti sp. nov.

4. Elytra shorter, ratio length/width $<1.70$; lateral margin of pronotum basad more convex (Figure 2); aedeagus see Figure 19

M. pearsoni sp. nov.

Elytra longer, ratio length/width $>1.80$, lateral margin of pronotum basad less convex (Figure 3); aedeagus unknown M. maini sp. nov.

\section{KEY TO THE SPECIES OF GRACILANILLUS GEN NOV.}

1. Body size smaller, length $<1.20 \mathrm{~mm}$, aedeagus unknown.

Body size larger, length $>1.40 \mathrm{~mm}$ 3

2. Elytra longer and narrower, ratio length/width 2.04; pronotum wider, ratio w/1 1.11, with wider base, ratio base/apex 0.96 , near base not sinuate (Figure 8) G. minutus, sp. nov.
Elytra shorter and wider, ratio length/width 1.95; pronotum narrower, ratio w/l 1.02, with narrower base, ratio base/apex 0.79 , near base sinuate (Figure 12) G. cordatus, sp. nov.

3. Elytra very narrow and elongate, ratio length/ width $>2.13$; body size slightly smaller, length $<1.50 \mathrm{~mm}$; pronotum not sinuate in basal half (Figures 7, 9-10); aedeagus unknown 4

Elytra slightly wider and shorter, ratio length/width 2.08; body size slightly larger, length $1.58 \mathrm{~mm}$; pronotum faintly sinuate in basal half (Figure 11); aedeagus see Figure 23 .......... G. cockingi sp. nov.

4. Pronotum wider, ratio length/width 1.14 , very shortly excised immediately in front of base (Figure 9) G. currani sp. nov.

Pronotum narrower, ratio length/width $<1.0$; not excised in front of base (Figures 7, 10) ................ 5

5. Base of pronotum relatively wider, ratio base/apex 0.98 , basal angle almost rectangular; elytral sulcus faint and only in basal third perceptible (Figure 10) G. vixsulcatus $\mathrm{sp}$. nov.

Base of pronotum relatively narrower, ratio base/ apex 0.88 ; basal angle obtuse; elytral sulcus distinct and complete (Figure 7)

G. longulus sp. nov.

\section{KEY TO THE SPECIES OF HESPERANILLUS GEN NOV.}

1. Body size larger, length $>1.75 \mathrm{~mm}$; pronotum narrower, ratio width/length $<1.20$; lateral margin of pronotum near base distinctly excised (Figures 13, 15)

Body size smaller, length $<1.50 \mathrm{~mm}$; pronotum wider, ratio width/length c. 1.32; lateral margin of pronotum near base barely excised (Figure 14); aedeagus unknown H. laticollis sp. nov.

2. Elytra longer and narrower, ratio length/width 1.84, almost parallel-sided, without longitudinal ridges; lateral margin of pronotum deeply excised near base (Figure 13); aedeagus see Figure 24

H. scanloni sp. nov.

Elytra shorter and wider, ratio length/width 1.65, reversely oviform; surface with two distinct ridges; lateral margin of pronotum shortly and faintly excised near base (Figure 15); aedeagus unknown H. bicostatus sp. nov. 

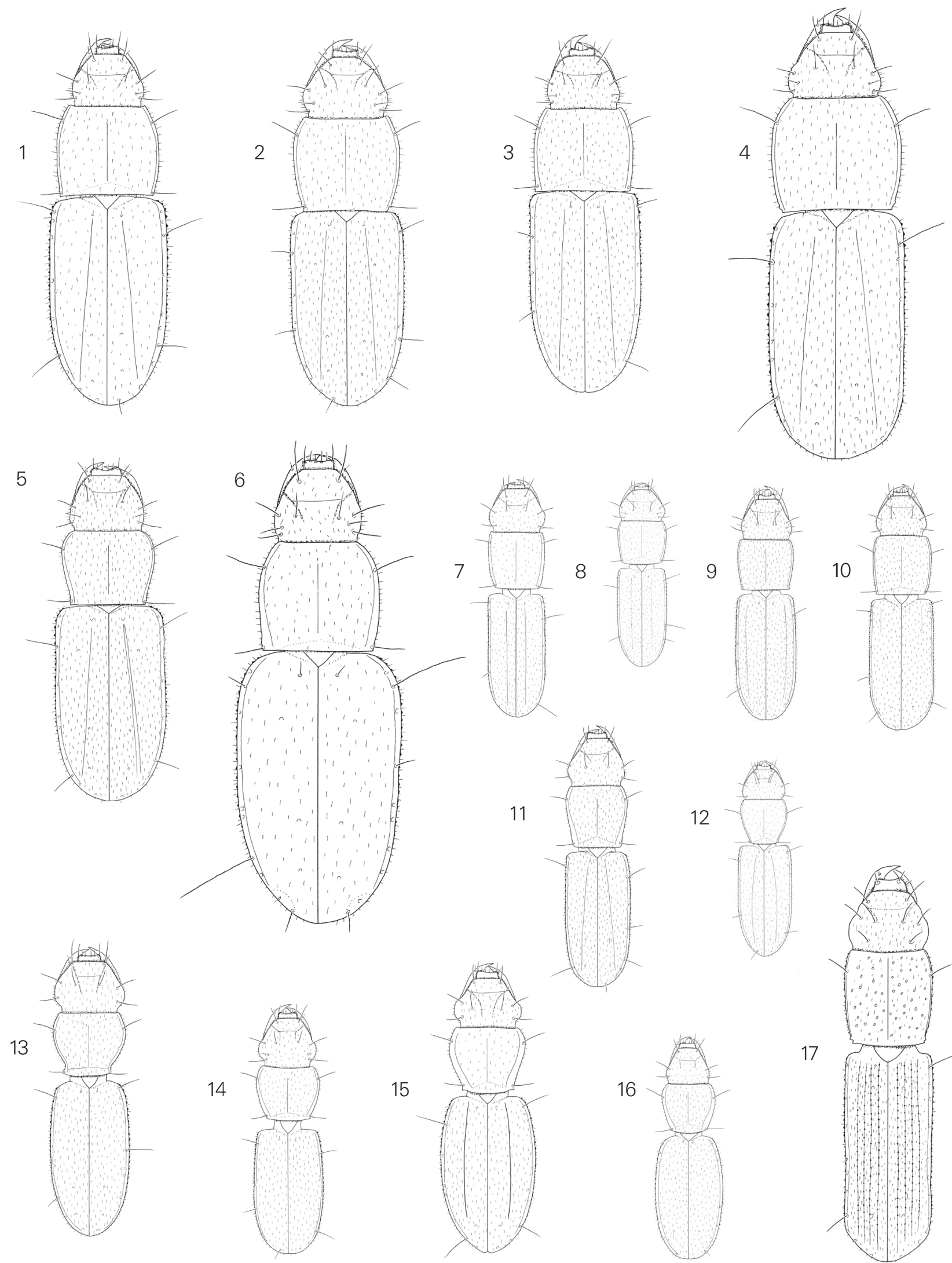

8

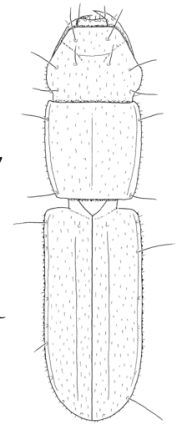

11

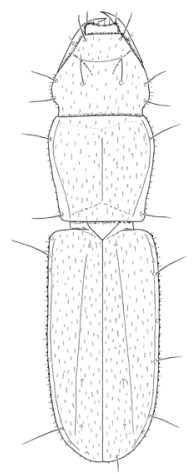

9

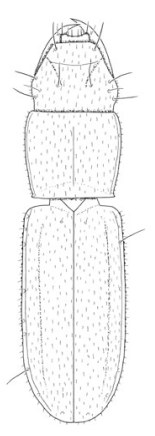

10

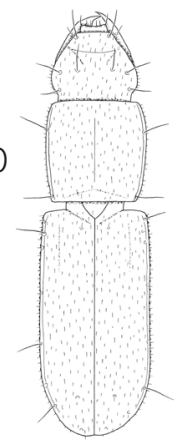

12

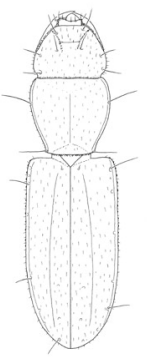

16

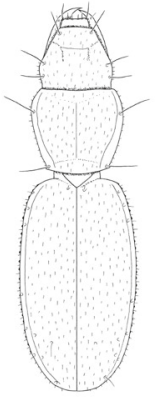

17
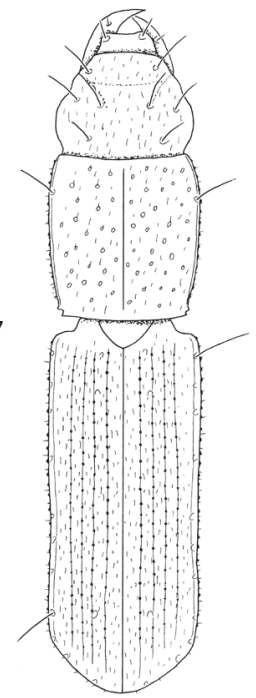

FIGURES 1-17 Habitus. Body length in brackets. 1, Macranillus bennetti sp. nov. (2.3 mm); 2, M. pearsoni sp. nov. (2.3 $\mathrm{mm}) ; 3$, M. maini sp. nov. $(2.2 \mathrm{~mm}) ; 4, M$. magnus sp. nov. $(2.8 \mathrm{~mm}) ; 5$, M. quartermaini sp. nov. (2.1 $\mathrm{mm}) ; 6$, Pilbaranillus latibasis sp. nov. (2.45 mm); 7, Gracilanillus longulus sp. nov. (1.48 mm); 8, G. minutus sp. nov. (1.15 mm); 9, G. currani sp. nov. (1.40 mm); 10, G. vixsulcatus sp. nov. (1.48 mm); 11, G. cockingi sp. nov. (1.58 mm); 12, G. cordatus sp. nov. (1.20 mm); 13, Hesperanillus scanloni sp. nov. (1.78 mm); 14 , $H$. laticollis sp. nov. (1.50 mm); 15, H. bicostatus sp. nov. (1.76 mm); 16, Externanillus mcraeae sp. nov. (1.35 mm); 17, Angustanillus striatipennis sp. nov. (2.4 mm). 
TABLE 1 Summary of measurements and ratios of the species of the genera Macranillus, Pilbaranillus, Gracilanillus, Hesperanillus, Externanillus and Angustanillus. N: number of specimens measured; L: body length in $\mathrm{mm}$; W: width in $\mathrm{mm}$; I/W pr: ratio length/width of pronotum; b/a pr: ratio width of base/width of apex of pronotum; I/w el: ratio length/width of elytra; 10th: ratio length/width of 10th antennomere.

\begin{tabular}{|c|c|c|c|c|c|c|c|}
\hline & $\mathrm{N}$ & $\mathrm{L}$ & W & $\mathrm{l} / \mathrm{wpr}$ & $\mathrm{b} / \mathrm{a} \mathrm{pr}$ & I/w el & 10th \\
\hline \multicolumn{8}{|l|}{ Macranillus } \\
\hline bennetti & 5 & $2.15-2.4$ & $0.72-0.84$ & $1.16-1.18$ & $1.19-1.21$ & $1.73-1.77$ & 1.25 \\
\hline pearsoni & 2 & $2.25-2.3$ & $0.75-078$ & $1.15-1.17$ & $1.10-1.14$ & $1.65-1.70$ & 1.2 \\
\hline maini & 2 & $2.2-2.4$ & $0.75-0.80$ & $1.18-1.22$ & $1.12-1.14$ & $1.80-1.81$ & 1.2 \\
\hline magnus & 2 & $2.8-2.85$ & $0.87-0.92$ & $1.08-1.09$ & $1.19-1.21$ & $1.77-1.78$ & 1.3 \\
\hline quartermainei & 4 & $2.0-2.45$ & $0.69-0.82$ & $1.17-1.21$ & $1.05-1.07$ & $1.75-1.78$ & 1.2 \\
\hline
\end{tabular}

Pilbaranillus

latibasis

0.9

1.02

1.25

1.64

1.3

\section{Gracilanillus}

longulus

minutus

currani

vixsulcatus

cockingi

cordatus

\section{Hesperanillus}

scanloni

laticollis

bicostatus

\section{Externanillus}

mcraeae

1

1.35

1.48

1.15

1.40

1.48

1.58

1.20

1.78

c. 1.50

1.76
0.54

1.18

0.77

c. 1.32

1.20

c. 0.78

0.88

1.65

1.84

1.25

1.15

1.15

\section{Angustanillus}



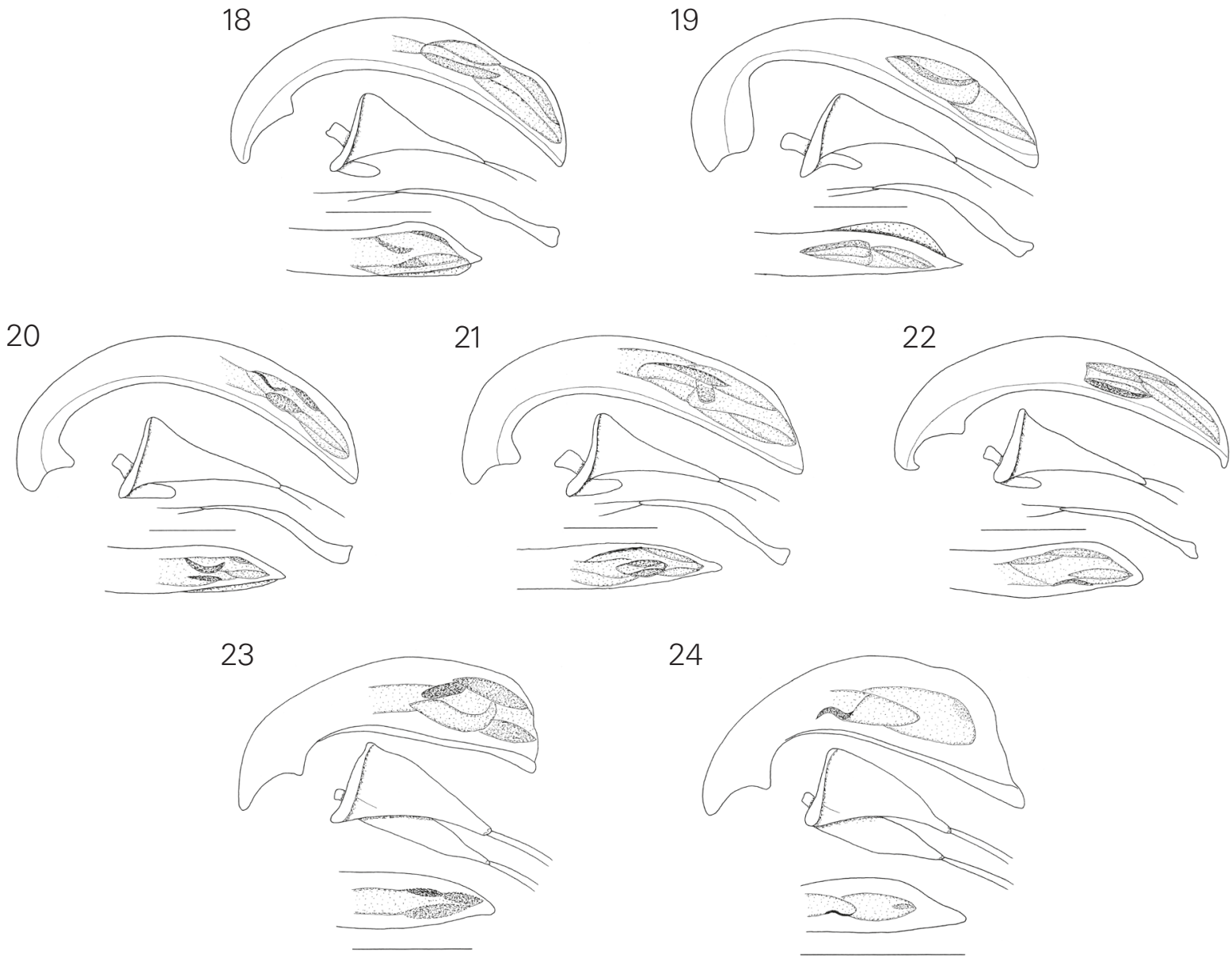

FIGURES 18-24 Male genitalia: aedeagus, left side, lower surface, left and right parameres. 18, Macranillus bennetti sp. nov.; 19, M. pearsoni sp. nov.; 20, M. magnus sp. nov.; 21, M. quartermaini sp. nov.; 22, Pilbaranillus latibasis sp. nov.; 23, Gracilanillus cockingi sp. nov.; 24, Hesperanillus scanloni sp. nov. Scale bars: 0.1 $\mathrm{mm}$.
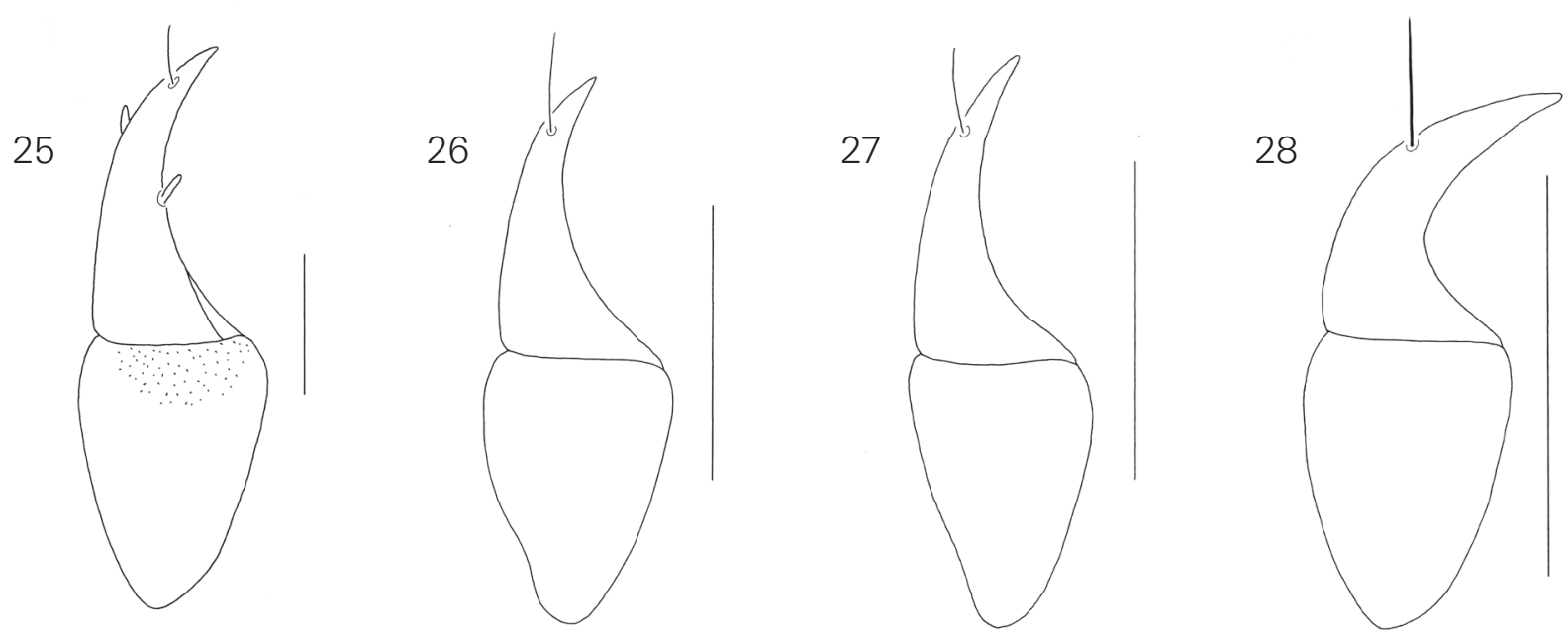

FIGURES 25-28 Female gonocoxites 1 and 2. 25, Macranillus magnus sp. nov.; 26, Gracilanillus vixsulcatus sp. nov.; 27, Hesperanillus bicostatus sp. nov.; 28, Externanillus mcraeae sp. nov. Scale bars: 0.05 mm. 


\section{REMARKS}

The present sample of eyeless Anillina from Western Australia not only greatly enlarges the number of species, but also remarkably extends the recorded range of this subtribe in Australia. Moreover, in view of the restricted area where subterranean fauna sampling was employed, and the scattered localities within that area, the actual number of Anillina species within Western Australia, and probably other parts of Australia, is likely to be high. Demonstrating this richness will require more systematic and widespread subterranean sampling. The record from near Norseman in the southern Yilgarn, for example, demonstrates that the range of hypogean Anillina is not restricted to the Pilbara.

All species of Anillina known to date from Western Australia are considered to be hypogean, i.e. they have been sampled from more or less deep bores in the ground. That is in contrast to all eastern Australian species that have been collected in leaf litter and the uppermost ground stratum. The occurrence deep in the earth, for some species at a depth of up to $60 \mathrm{~m}$, is unique to Anillini. However, the absence of such records from other parts of the world may be due to the fact that trapping and scraping of deep drill holes is a technique very rarely used outside Western Australia.

With respect to the composition of Anillina species in samples collected in Western Australia, the large species of Macranillus tend to be more numerous in samples, whereas the small species of Gracilanillus, Hesperanillus, Externanillus, and Angustanillus were nearly always represented by a single specimen in a sample. Based on current knowledge, it is uncertain whether this is due to greater abundance of the larger species or to some artefact of sampling. What is clear is that a rich subterranean anilline fauna occurs in the Pilbara, with apparently very restricted ranges of all species. No species was collected at localities more than $2 \mathrm{~km}$ apart and they represent extreme short range endemics (sensu Harvey 2002).

Of the three new genera for which more than a single species has been found, the five species of Macranillus are remarkably homogenous in body shape and structure, and they differ only in body size and relative length or width of the prothorax and elytra. The male genitalia likewise are quite similar. Most peculiar are $M$. magnus by virtue of its large size and $M$. quartermainei in view of its slightly cordiform prothorax. The single species of Pilbaranillus has a similar body size to Macranillus but it lacks the elytral sulcus; in addition, the shape of the elytra, particularly the rounded humerus, and shape of the aedeagus are quite different.

The single species of Angustanillus likewise is large, but is unique in its very distinct striation of the elytra, which is very uncommon in Anillina generally. However, it matches particularly the species of Gracilanillus in its extremely narrow and elongate elytra.
Most species of Gracilanillus are quite homogenous in body shape and structure, only G. cordatus differs in its slightly cordiform prothorax, and G. vixsulcatus differs in its barely perceptible elytral sulcus. However, the elytral sulcus is very weak in all species of Gracilanillus and is fairly difficult to detect in some other species as well.

The species of Hesperanillus are morphologically much more diverse. However, they have in common the remarkably protruded eye area which is unique for this genus. Whereas $H$. scanloni and $H$. laticollis are reasonably similar in body shape, $H$. bicostatus is distinguished by its short, wide, and bicarinate elytra. Therefore Hesperanillus is a genus of convenience and may be revised in the future, after the possible discovery of additional species, new characters, and new relationships.

The single species of Externanillus is probably most closely related to Hesperanillus but differs in its smaller head with far less developed eye area, narrower prothorax, and more oval-shaped elytra.

Compared with the genera recorded from estern Australia, most western genera and species are quite differently shaped and structured. The Anillina currently known from Australia can be roughly divided into genera that possess a longitudinal elytral sulcus, and those that lack this sulcus. Of genera known prior to this paper, only Illaphanus possesses the sulcus; the three others, Pseudillaphanus, Austranillus, and Tasmanillus lack it. Of the new western genera two, namely Macranillus and Gracilanillus, possess the sulcus, Pilbaranillus, Hesperanillus, Externanillus, and Angustanillus do not. However, in body shape, particularly in shape of the prothorax and elytra, Macranillus and Gracilanillus differ markedly from Illaphanus.

In its wide pronotum Pilbaranillus is fairly similar to the eastern genus Austranillus that is known from a single specimen from southern New South Wales. The former is much smaller, has differently shaped and structured elytra, and the chetotaxy of the head and elytra is also different. Hesperanillus differs from all eastern genera that lack the elytral sulcus in different ways, e.g. in the shape of the prothorax, shape of elytra, and the very large head with the remarkably prominent eye area. While Giachino (2005) considers presence of the elytral sulcus to be an apomorphic character state, in view of the weak development of the sulcus in certain otherwise very similar species of Gracilanillus, this character may be of less phylogenetic value than first thought.

In conclusion, even though the relationships between the western genera still remain obscure, mainly due to the uncertain phylogenetic value of presence, or absence, of the elytral sulcus, it seems that the western genera form a group of species that are more strongly related to each other, than to any of the eastern genera. 


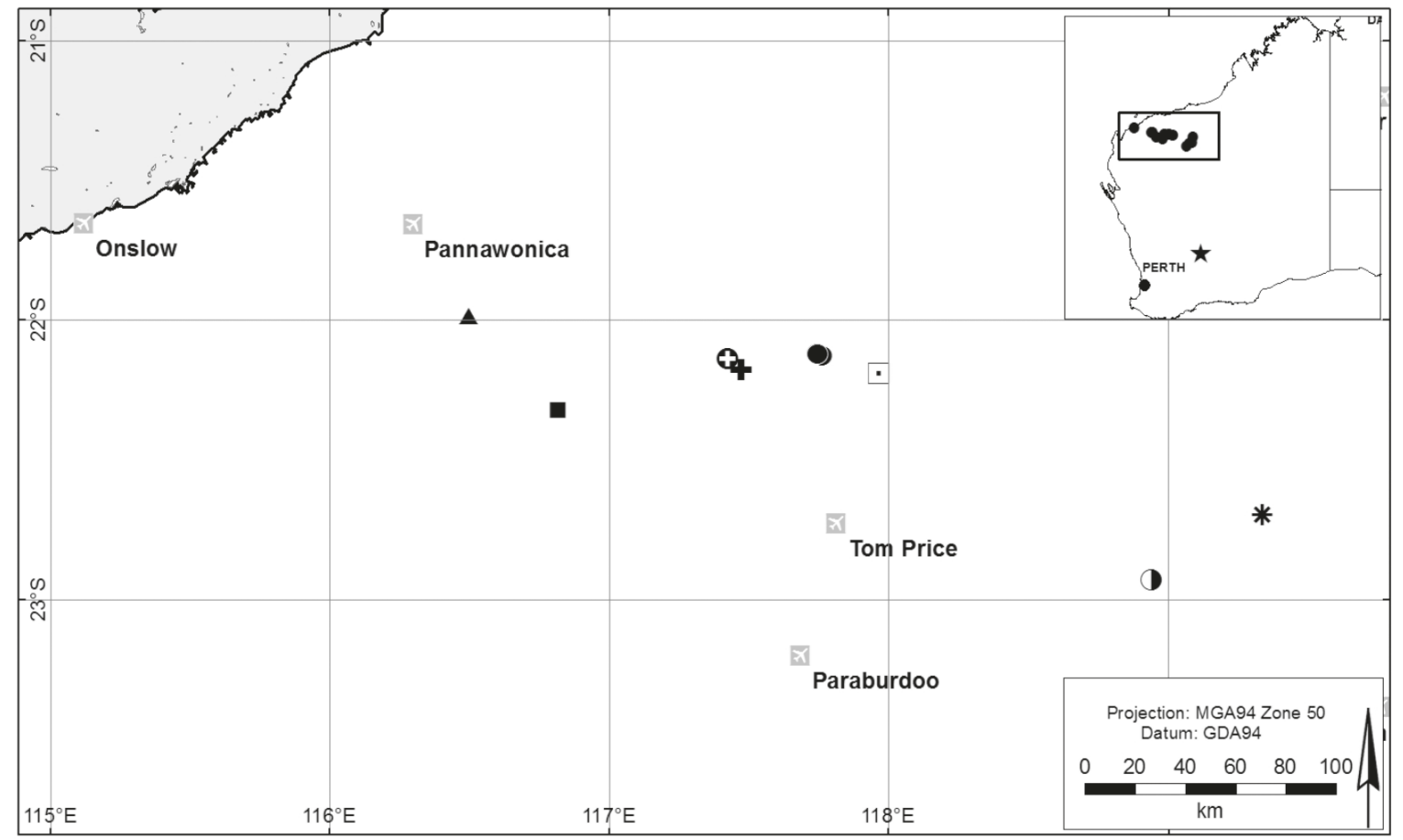
- Gracilanillus cockingi
- G. Iongulus
* G. vixsulcatus
- Hesperanillus bicostatus
+ H. laticollis
- Macranillus bennetti
$\boldsymbol{\oplus}$ M. pearsoni
- M. quartermainei

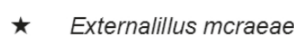

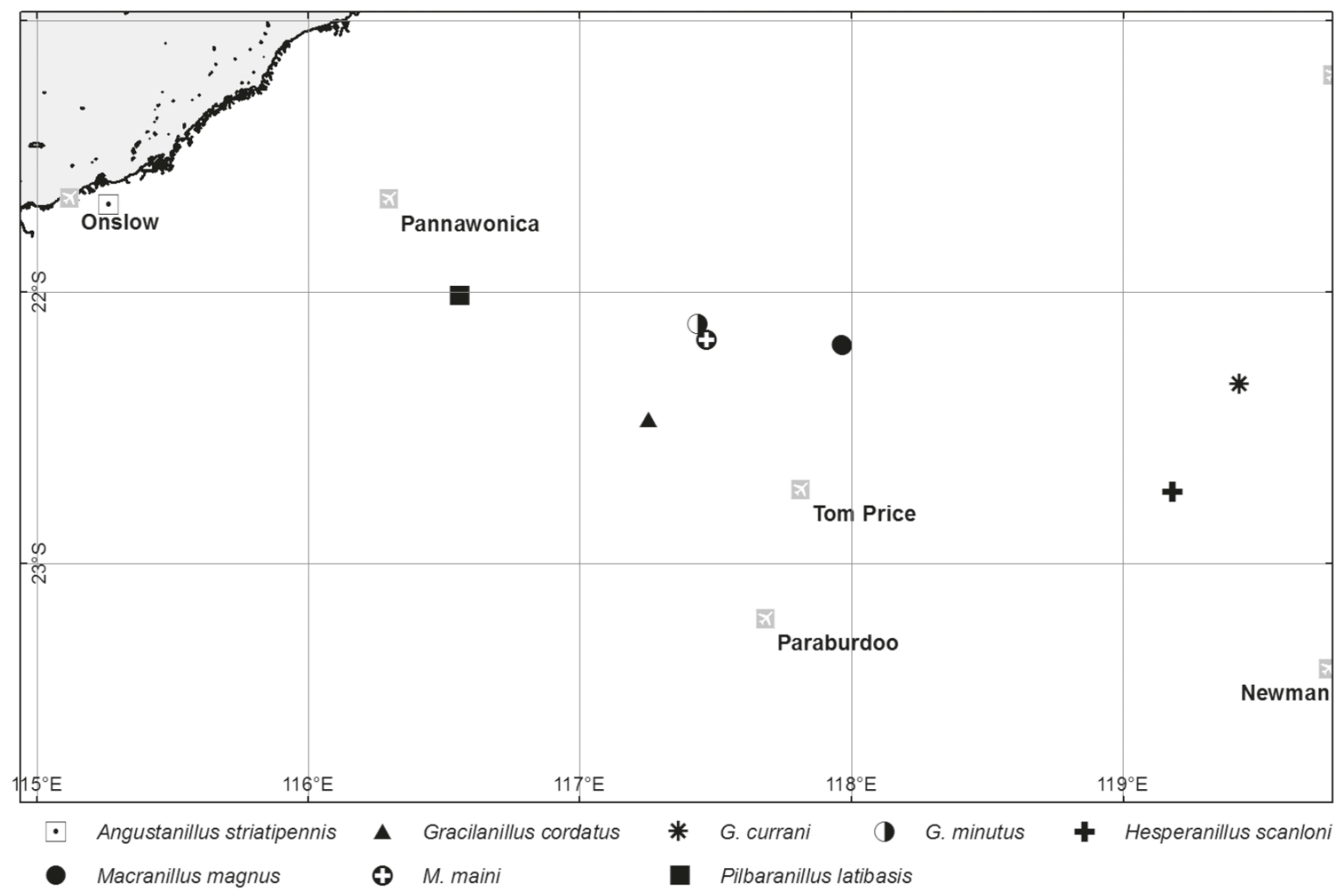


A further difference between most eastern and western genera is the narrow and elongate body shape of almost all western species, in contrast to the short and ovoid shape of the elytra and the markedly cordiform prothorax of all eastern species except the single species of Austranillus. It may be speculated that the parallelsided shape of so many western species represents an adaptation to the life deep in the ground, in narrow fissures between the thin layers of stratified sandstone which is widely distributed throughout the Pilbara. The value of such a slender shape for hypogean habits still has to be verified.

Giachino (2005) presented some thoughts about phylogeny and biogeography of the Australian Anillina and pointed out the long history of Anillina in eastern Australia. According to Giachino, in Australia Anillina were present at least in pre-Tertiary time, probably since $85 \mathrm{MY}$, because they were also recorded from Norfolk and Lord Howe Islands. Anillina in general are regarded as a 'Gondwanan' faunal element (Jeannel 1963, Giachino 2004) that probably originated before the separation of India from the Gondwanan continent. Therefore the presence of a rather rich Anilline fauna in Australia is not too surprising. However, no one has previously questioned why Anillina apparently occur only in eastern Australia and in rather wet, well forested areas. This was probably because Anillina were thought to occur only in ground litter and thus can be adequately sampled by sieving litter, principally in forested areas. As a consequence, they were not looked for in the vast semiarid and arid regions of central and western Australia. Using drill holes to sample subterranean habitats has not only changed and improved our knowledge of the habitats of Australian Anillina but has also demonstrated that the group is likely to occur across most of Australia.

The occurrence of Anillina in Western Australia matches well their putative Gondwanan origin and history, because we know of other old Gondwanan faunal elements that are particularly numerous in semiarid Western Australia: in carabid beetles for example, the circumtropical genus Megacephala (sensu lato) is far more numerous in Western Australia, in terms of species, than in the east.

\section{ACKNOWLEDGEMENTS}

We are indebted to Kym Abrams, Nadine Guthrie, Brian Hanich, and Nicolai Tatarnic (Perth) for the kind loan of the specimens to MB.

\section{REFERENCES}

Baehr, M. (2014a). Two new species of the genus Pogonoglossus Chaudoir from the Pilbara, north-western Australia (Insecta: Coleoptera: Carabidae: Physocrotaphini). Records of the Western Australian Museum 29: 89-94.

Baehr, M. (2014b). Two new species and a new genus of Zuphiini from the Pilbara, north-western Australia (Insecta: Coleoptera: Carabidae: Zuphiini). Records of the Western Australian Museum 29: 95-104.

Bouchard, P., Bousquet, Y., Davies, A. E, Alonso-Zarazaga, M. A., Lawrence, J. F., Lyal, C. H. C., Newton. A. F., Reid, C. A. M., Schmitt, M., Slipinski. S. A. \& Smith, A. B. T. (2011). Family-group names in Coleoptera (Insecta). ZooKeys 88 (Special Issue): 1-971.

Giachino, P. M. (2004). New Anillina (Coleoptera, Carabidae: Bembidiini) of the Oriental Region. In: Cuccodoro, G. \& Leschen, R. (eds): Systematics of Coleoptera: papers celebrating the retirement of Ivan Löbl. Memoirs on Entomology International, Gainesville 17: 21-51.

Giachino, P. M. (2005). Revision of the Australian Anillina (Coleoptera, Carabidae, Bembidiini). Monografie de Museo Regionale di Scienze naturali di Torino 42: 137-238.

Halse, S. A. \& Pearson, G. B. (2014). Troglofauna in the vadose zone: comparison of scraping and trapping results and sampling adequacy. Subterranean Biology 13: 17-34.

Harvey, M. (2002) Short-range endemism among the Australian fauna: some examples from non-marine environments. Invertebrate Systematics 16: 555-570.

Jeannel, R. (1937). Les Bembidiides endogées (Col. Carabidae). Monographie d'une lignée gondwanienne. Revue française d'Entomologie 3: 241-396.

Jeannel, R. (1963). Monographie des "Anillini”. Bembidiides endogés (Coleoptera Trechidae). Mémoirs du Museum national de l'Histoire naturelle. 28 (Série A, Zoologie): 33-204.

Lorenz, W. (2005). Systematic list of extant ground beetles of the world (Insecta Coleoptera "Geadephaga": Trachpachidae and Carabidae incl. Paussinae, Cicindelinae. Rhysodidae). 2nd ed. Printed by the author, Tutzing. 530 pp.

Macleay, W. J. (1865). Description of a new genus of carabideous insects. Transactions of the Entomological Society of New South Wales 1: 155-157.

Moore, B. P., Weir, T. A. \& Pyke, J. E. (1987). Rhysodidae and Carabidae. Zoological Catalogue of Australia 4: 17-320.

Moravec, P, S.-I. Uéno \& Belousov, I. A. (2003) Tribe Anillini Jeannel, 1937. In: Löbl, I. \& Smetana, A. (eds), Catalogue of Palaearctic Coleoptera, Vol. 1. Archostemata-Myxophaga - Adephaga: 237-241.

MANUSCRIPT RECEIVED 13 OCTOBER 2015; ACCEPTED 15 NOVEMBER 2016. 